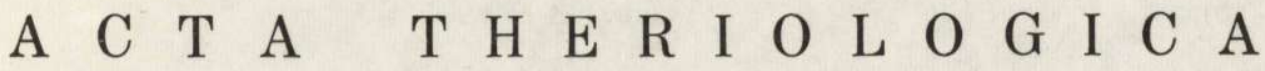 \\ VOL. $18,7: 125-165$ \\ BIAEOWIEŻA \\ August, 1973
}

Lech RYSZKOW SKI, Jacek G OSZCZYŃSK I

\& Janusz TR U S Z KO W S K I

\section{Trophic Relationships of the Common Vole in Cultivated Fields*}

[With 19 Tables \& 7 Figs.]

\begin{abstract}
On the area of 3,100 ha of cultivated fields the density of the following species of rodents was estimated: $M$. arvalis in fields and C. glareolus, A. flavicollis and A. agrarius in woods. At the same time the numbers of predatory nammals and birds were estimated. During the whole period of study in area under examination $3,400,000$ individuals of $M$. arvalis and 43,000 of forest rodents were present. Between the depression and the peak of numbers the density of $M$. arvalis increased over one hundred.times. At the density of 44 individuals/ha the voles consumed in a year $79 \mathrm{~kg}$ d.w. of alfa-alfa/ha, and at $774 \mathrm{indiv} . / \mathrm{ha}$ as much as $1,153 \mathrm{~kg}$ d.w./ha. It was demonstrated that the ratio of plant weight destroyed to consumed amounted in alfa-alfa cultures to 1.8:1. At a low density af $M$. arvalis considerable losses of winter rye during winter are compensated by the regrowth of plants in spring. Food requirement of predators was determined and their diet in field conditions was investigated. The highest number of $M$. arvalis was consumed by foxes, lower by cats and weasels. The predators hunted mainly in areas showing the highest rodent density. With the increased numbers of $M$. arvalis its share in the diet of all predators rose up to $80 \%$. Despite this the pressure of predators on the population of $M$. arvalis decreased, e.g. in the year of outbreak the predators removed barely $10.8 \%$ of all present individuals. With the increased proportion of $M$. arvalis in the diet of fox the proportion of consumed hares decreases. A scheme of trophic relationships of $M$. arvalis is presented.
\end{abstract}

\section{INTRODUCTION AND STUDY AREA}

Comprehensive understanding of the importance of the common vole, Microtus arvalis ( $\mathrm{P}$ a 11 a s, 1779), in the trophic relationship of cultivated fields is still incomplete despite a large number of ecological studies concerning this species, as manifested by the publication of two monographs (K r a tochvil, 1959; $\mathrm{B}$ a š e $\mathrm{n}$ i $\mathrm{n}$ a, 1962). Existing historical notes indicate that since ancient times $M$. arvalis has been recognized

* Praca została wykonana w ramach problemu węzłowego 09.1.7., koordynowanego przez Instytut Ekologii PAN. 
as a pest in agriculture (E 1 to $n, 1942)$. Such opinion persisted until now and this emphasizes economical importance of this species. The role played by common voles in trophic relationships of an ecosystem depends on their effects on plants, as well as on contribution of voles as an important source of food for vertebrate predators occurring in cultivated fields.

The effects of common voles on plants, especially those manifesting as crop damages (e.g. Krat o chvil, 1959; B a š en in a, 1962; M aksimov, 1964), are much better understood than the trophic importance of voles for predators. The latter question can be examined from two standpoints: (1) how changes in the numbers of field voles affect the diet of predators, or in other words how they affect intensity of hunting of the predators for other prey species, e.g. for game, (2) how much the pressure of predators affects population numbers of field voles.

Both these important ecological problems will be discussed in the present paper.

During the investigations of the effect of $M$. arvalis on plants a particular attention has been paid up to now to the estimation of both direct consumption and total losses caused by damages in the vegetation. It is known that only a part of destroyed plants is consumed by herbivorous animals, while the other part is utilized by various above ground and soil heterotrophs of an ecosystem. This problem was investigated for alfa-alfa cultures. On the other hand, the compensatory growth of plant biomass in effect of damages caused by herbivorous animals belongs to rather poorly understood ecological phenomena. The problem is particularly important for overwintering crops and perennial plants which constitute the main source of food for $M$. arvalis in winter. The results of investigations on this subject concern the plantations of overwintering rye.

In the Department of Agroecology long-term investigations were undertaken in 1969 on rodents and their predators in the agricultural landscape of Southern Wielkopolska. In the initial period the investigations were concentrated on a small area (around $150 \mathrm{ha}$ ) including a forest and adjoining plantations (R y sz k owski, Wagner, Goszczyński \& Truszkowski, 1971). Since 15 October 1970 till 31 March 1972 the rodents and their predators were investigated on the area of $3100 \mathrm{ha}$. The study area is located at the Kościan Plain lying in the western part of the zone of Central Lowlands of Poland. There prevail sand-loamy soils on loam, and sandy soils on loam. The proportion of arable land is considerable and constitutes $69.3 \%$ of the total study area (Table 1).

The land is intensively cultivated, as indicated by the amount of employed mineral fertilizers (the mean for the whole cultivated area amounted in 1971 to 180 $\mathrm{kg} / \mathrm{ha}$ of nitrogen, potassium and phosphorus), by mechanized agricultural work, and by utilization of chemicals against pests and weeds. On poorer soils the 
following crop rotation is usually employed: potatoes, oat, rye, vetch or lupin, maize and rye, while on better soils: sugar-beet, barley, leguminous crops, rape and wheat. Maize is often cultivated as a fodder for cattle.

Apart from forests the study area includes several small woods, of the cluster or band type, resulting from a long-term action of afforestation of agricultural landscape. The first woods in the fields were established by D. Chlapowski in the first half of 19 century. Both forests and woods form suitable habitats for the game and predatory mammals and birds. Among the game the following animals occur quite often: roe-deer, Capreolus capreolus (L in n a e u s, 1758), hare, Lepus europaeus (Pallas, 1778), and wild boar, Sus scrofa Linnaeus, 1758. Common mammalian predators include: fox, Vulpes vulpes (L innae us, 1758), pine marten, Martes martes ( $\mathrm{Linn}$ a u s, 1758); beech marten, Martes foina (Erxleben, 1771); badger, Meles meles (Linnae us, 1758), weasel, Mustela nivalis Linna u s, 1766, and as will be shown later house cat, Felis catus (L in-

Table 1

Spatial structure of habitats in the vegetation period.

\begin{tabular}{lcc}
\hline \multicolumn{1}{c}{ Type of habitat } & $\begin{array}{c}\text { Area, } \\
\text { hectares }\end{array}$ & Pre cent \\
\hline 1. Forests and woods & 392.9 & 12.8 \\
2. Perennial cultures & & 16.1 \\
(alfa-alfa, clover, meadows) & 500.5 & 2.1 \\
3. Overwintering rape & 64.5 & 24.1 \\
4. Overwintering corns & 746.0 & \\
5. Spring cultures & & 17.5 \\
$\quad$ (corns, vetch, pea, & 543.8 & 19.7 \\
bird's-foot, lupin, etc.) & 612.3 & \\
6. Root crops and maize & & 7.7 \\
7. Waste lands & 241.0 & 100.0 \\
(buildings, roads, ponds, & irrigation canals) & \\
Total & &
\end{tabular}

Note. In winter the area of ploughed fields amounts to 958 ha or $31 \%$ of the whole area. Crops, mainly rye, fo: fodder are cultivated on the area of 199 ha or $6.4 \%$.

n a e us, 1758) should also be regarded as an important predator. Among birds the following predators are fairly common: three species of owl - Strix aluco (L inn a e u s, 1758), Tyto alba (S c opoli, 1769) and Asio otus (Linnae us, 1758), and two species of buzzards - Buteo buteo (Linnae us, 1758) and in winter Buteo lagopus (B r üm i c h, 1762).

The field vole is the most common rodent species in the fields, while in forests and woods there prevail bank vole Clethrionomys glareolus (S c h rebe r, 1780), and mice Apodemus flavicollis ( $\mathrm{Mel} \mathrm{ch}$ ior, 1834) and Apodemus agrarius (P a l1 a s, 1771). The last species is also found occasionally in cultivated fields.

Taking into consideration different degree of utilization of the environment by rodents the following types of habitats have been distinguished (Table 1):

(1) Forests and woods inhabited by typical forest species such as C. giareolus, A. flavicollis, and to a considerble degree also by $A$. agrarius.

(2) Cultures of perennial plants: meadows, alfa-alfa and clover plantations 
constituting the best habitat for $M$. arvalis. In the unfavourable periods these area represent a refuge for the field vole.

(3) Plantations of overwintering rape.

(4) Plantations of overwintering corns. The last two types of cultures create relatively favourable conditions for wintering and for spring reproduction of common voles. During winter the soil is covered by vegetation and in spring is not ploughed. Rape cultures are characterized by a higher number of voles than corn cultures. This is probably related to earlier sowing of rape (August in comparison with late September or the first half of October in the case of corns), as well as to a higher feeding value of rape.

(5) Spring plantations, mainly spring corns ${ }^{1}$. This habitat is in winter devoid of vegetation, and in spring agrotechnic measures before sowing coincide with the beginning of intensive breeding of field voles. Growth of plants in the fields occurs usually when the first spring generation of yoles leaves the nests in other plantations.

(6) Root crops and maize. In the period of investigations these plantations were not inhabited by the common vole. During three years of observations no colonies of voles were observed in the cultures of potatoes and maize. The rodents captured there represent migrating individuals.

(7) Waste lands (buildings, roads, irrigation canals, ponds). Although the investigated rodent species may occur in these habitats (e.g. in shoulder of roads, or winter in barns), the method of determinating their density there is lacking hence the waste lands were neglected in the estimations of predators pressure on rodents. In relation to the whole study area the area of waste lands amounts to $7.7 \%$ (Table 1 ).

In the vegetation period all the mentioned types of habitats can be found in the study area. In winter approximately $30 \%$ of the arable land are occupied by ploughed fields, which in spring will be used for root crops and spring plantations. Some of the fields in winter are occupied by second crops (mainly rye) cut by the end of April or in early May as forage for cattle. Despite more dense sowing this habitat resembles cultures of overwintering corns. The structure of main types of plantations (Table 1) remains rather stable for several years. The fluctuations within three years (1969-1971) were very small.

\section{ESTIMATION OF DENSITY AND TOTAL NUMBER OF PRESENT RODENTS}

\subsection{Field Rodents}

\subsubsection{Methods of Capture and Estimation of the Number of Present Individuals}

The density of $M$. arvalis was estimated by flushing with water voles away of their burrows on the area of $625 \mathrm{~m}^{2}(25 \times 25 \mathrm{~m})$. The captured individuals were weighed and their sex determined. Trappings were carried out in several - to a few dozens - samples from different fields in particular types of habitats (Table 2) three times during the year: in

${ }^{1}$ Plantations of the vetch, pea, bird's-foot, field pea, lupin and the like belong also to this type. 
spring (April-May), summer (July-August) and autumn (November). Altogether 410 trappings were carried out and 2750 individuals of $M$. arvalis were captured. In order to verify the accuracy of the method of density estimation the number of individuals captured in three consecutive floodings of the burrows on the same sampling area in daily intervals were compared. In alfa-alfa plantations 17 such trappings were carried out obtaining altogether 990 individuals of $M$. arvalis. The individuals captured on the first day conștituted $79 \%$ of the total three-day trappings. In corn plantations 20 trappings were carried out. Altogether 120 individuals were captured, and the number of voles in the first day constituted as much as $93 \%$. Since it could be supposed that at least some of the individuals captured on the second or third day immigrated from

Table 2

Density of $M$. arvalis in plant cultures, number of individuals per ha (in brackets number of samples is given).

\begin{tabular}{|c|c|c|c|c|c|}
\hline Cultures & Autumn 70 & Spring 71 & Summer 71 & Autumn 71 & Spring 72 \\
\hline $\begin{array}{l}\text { Perennial } \\
\text { cultures }\end{array}$ & $44(10)$ & $112(14)$ & $1412(13)$ & $1450 \quad(4)$ & $125(15)$ \\
\hline $\begin{array}{l}\text { Overwintering } \\
\text { cultures }\end{array}$ & $5(104)$ & $22(25)$ & $84(45)$ & $84(33)$ & $40(41)$ \\
\hline $\begin{array}{l}\text { Winter rape } \\
\text { Spring } \\
\text { cultures }\end{array}$ & $20 *(8)$ & $4_{* *}^{41}(12)$ & $\begin{array}{c}131(26) \\
79(30)\end{array}$ & $204 \underset{*}{(15)}$ & $44 \underset{* *}{(15)}$ \\
\hline $\begin{array}{l}\text { Root crops } \\
\text { and maize }\end{array}$ & * & $*$ & ** & $*$ & $*$ \\
\hline $\begin{array}{l}\text { Numbers per mean } \\
\text { acreage of culti- } \\
\text { vated fields }\end{array}$ & $11(122)$ & $32(51)$ & 333 (114) & $332(52)$ & $42(71)$ \\
\hline
\end{tabular}

* This type of culture did not appear at crop pattern during indicated season. ** Lack of colony.

the neighbouring habitats the following modification was introduced: on the area of seven planned flooding plots live traps were set. The captured voles were individually toe clipped and released to burrows in the vicinity of capture. Immediately afterwards (in 10 minutes on the average) the whole colony was flooded with water. During seven trappings 83 marked voles were released; out of them only $69.5 \%$ were recaptured after flooding. The estimated accuracy of trapping $(69.5 \%)$ is lower than the estimation obtained during three consecutive flooding of the same area $(79 \%)$. Taking into consideration both estimates it was assumed that on the average $25 \%$ of individuals prosent in a given area was not registered during single flooding of burrows in alfa-alfa plantations. This correction of $25 \%$ was also assumed for rape cultures and for meadows 
due to a large degree of cover of the area by plants. In the case of trappings in corn plantations (overwintering and spring corns) the value of $7 \%$ correction for omitted individuals was assumed taking into account data obtained in three consecutive flooding of the same areas.

The mean estimates of voles density obtained in samples in particular habitats were accordingly corrected by 25 or $7 \%$.

Trappings of rodents provide information on their density in a given moment of time. To determine the pressure of predators the estimate of the total numebr of individuals $(V)$ present durnig the whole period of investigations is required. This was obtained in the following way: (a) after multiplying vole density by the number of days in a given interval of time we obtain a parameter called "individual-days «, (b) this parameter is divided by the mean longevity of the trappable part of population.

The result should correspond to the estimate of total number of present individuals $(V)$, under a condition that the initial state of population represents individuals born on the day of starting the investigations, and that all individuals will die on the day of the end of observations. In fact the individuals present at the beginning of investigations are of varied age and live for a shorter period than the mean longevity. Similarly the individuals present at the end of a given period of investigations could not achieve the expected average length of life.

The selection by the investigator of a stipulated date of keginning and end of observations causes that not all individuals could realize their mean longevity in a given period of time. This gives an error leading to underestimation; the error is higher with a shorter period of observations. In case of estimating the numbers in a large population it can be assumed that the individuals present at the beginning of observations lived already for a half of their average length of life. Similarly the individuals at the termination of observations will still live for a half of their longevity. By multiplying the number of individuals present at the beginning and end of a given period of investigations by half of the average length of life we can obtain a correction which should be added to the calculated value of individual-days. In such way we estimate the real value of individual-days which were survived by the animals present during the investigations. When this value is divided by the average length of life we obtain a not-underestimated number of present individuals $(V)$.

The average length of life of common voles equal to 60 days was calculated on the basis of data given by M a xim ov (1964) taken from studies of Januško \& Naumov, as well as Feniuk \& Šej$\mathrm{kin}$ assuming exponential survival curve. The suggestion of Spitz 
(1970) on variable mortality of $M$. arvalis cohorts born at different seasons was not taken into consideration due to the lack of any data.

The method described above was used to calculate the number of M. arvalis individuals present in the study area during the whole period of investigations. Additionally for the estimation of pressure of predators on these rodents in autumn-winter and spring-summer seasons three periods were distinguished: first - between 15 October 1970 and 31 March 1971; second (vegetation) - between 1 April 1971 and 31 Octoker 1971; third - between 1 November 1971 and 31 March 1972.

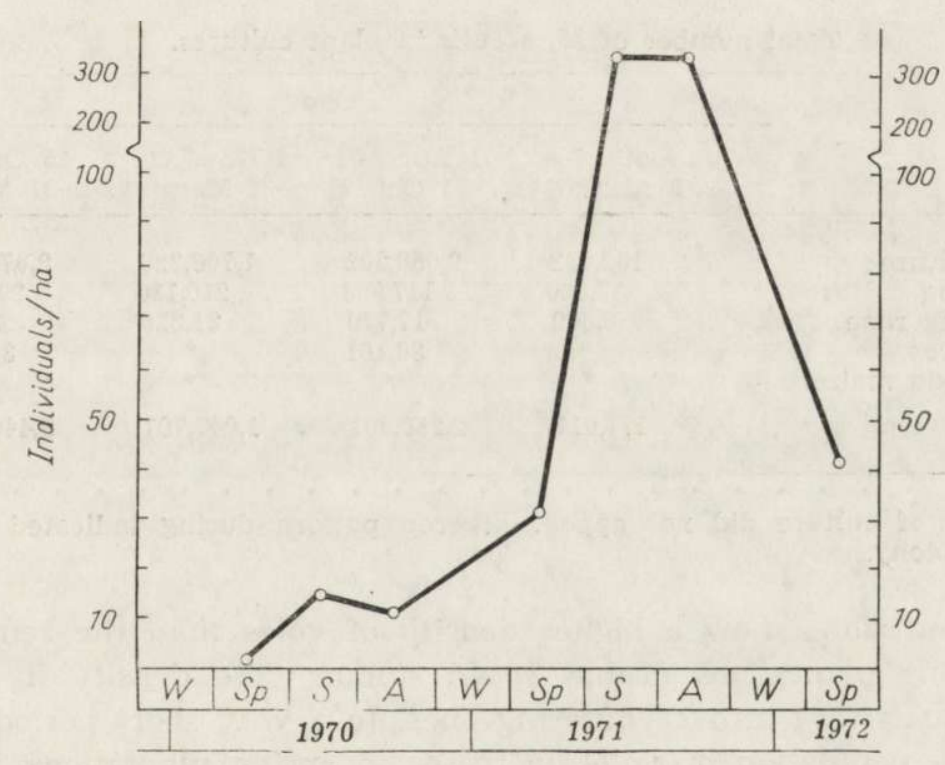

Fig. 1. Density of $M$. arvalis per average acreage of cultivated fields.

\subsubsection{Results}

The increase in the population of the common vole started in spring 1970 when the lowest density of approximately one individual per 1 ha of the arable land was observed (Ryszkowski et al., 1971). This trend of increase persisted until autumn 1971 (Fig. 1). As demonstrated by additionally obtained data the reproduction of voles occurred also in winter during the period under question (15 Oct. 1970 - 31 March 1972). In autumn 1971 the numbers in the vole population began to decrease. In spring 1972 the density was 8 times lower than in autumn 1971. 
During the whole period of investigations the highest density of voles was found in cultures of perennial plants (alfa-alfa), where in summer and autumn 1971 it reached 1400 individuals per 1 ha (Table 2). This habitat is certainly preferred by voles, probably due to a limited number of agrotechnic measures (lack of ploughing) and due to good feeding conditions during the whole year. The colonies of voles in alfa-alfa cultures and meadows are well developed and the corridors reach the depth of $80 \mathrm{~cm}$. For this reason any general change in the number of voles in agricultural landscape depends first of all on the situation in cultures of perennial plants.

Table 3

Total number of $M$. arvalis in plant cultures.

\begin{tabular}{|c|c|c|c|c|}
\hline \multirow[b]{2}{*}{ Cultures } & \multicolumn{4}{|c|}{ Period } \\
\hline & $\begin{array}{l}15 \text { Oct. }{ }^{70-} \\
-31 \mathrm{M}^{\text {ar }} 71\end{array}$ & $\begin{array}{l}\text { 1 April } 71- \\
-31 \text { Oct. } 71\end{array}$ & $\begin{array}{l}\text { 1 Nov. } 71- \\
-31 \text { March } 72\end{array}$ & $\begin{array}{l}15 \text { Oct. } 70- \\
-31 \text { March } 72\end{array}$ \\
\hline Perennial cultures & 132,632 & $2,058,302$ & $1,706,329$ & $3,076,073$ \\
\hline Overwintering cultures & 37,800 & 117,968 & 210,136 & 295,294 \\
\hline Overwintering rape & 6,579 & 17,770 & 31,326 & 42,250 \\
\hline Spring cultures & $*$ & 36,161 & $*$ & 36,161 \\
\hline Root crops and maize & * & $* *$ & $*$ & 0 \\
\hline Total & 177,011 & $2,230,201$ & $1,947,791$ & $3,449,778$ \\
\hline
\end{tabular}

* This type of culture did not appear at crop pattern during indicated season.

** Lack of colony.

Rape plantations show a higher density of voles than the remaining overwintering plantations (Table 2). In summer the density in spring cultures equals that in overwintering ones. In a very short period $(2-3$ months) the population of voles increases in spring plantations practically from zero to the value ocurring in overvintering plantations during the harvest. No resident voles were found in root crops, although snap-traps demonstrated that voles migrate through these plantations (Table 2).

In the vegetation period over 2,200,000 field voles inhabited the study area, and in the whole period of investigations - approximately $3,400,000$ voles (Table 3). The number of individuals occurring in particular types of habitats is a function of changes in the numbers registered by the estimates of density, and the size of area occupied by a given type of plantation in the general pattern of utilization of arable land. 


\subsection{Forest Rodents}

2.2.1. Method of Estimation of Numbers and the Total Number of Present Individual

In forest habitats the estimations of rodents density were carried out according to the modified standard minimum method ( $\mathrm{Grodzinski}$, Pucek \& Ryszkowski, 1966). A trapping grid corresponded to 10 rows and 10 lines of prebaiting points separated from each other by $15 \mathrm{~m}$. The bait (flour mixed with margarine) was tagged with coloured wool according to $\mathrm{Hol}$ is o v a (1968) and was placed on the grid during three following days. In the central square (six internal rows and lines) a different colour of bait was used them in an outer belt. Then at each prebaiting point two snap-traps were set and were inspected daily for three days. The trapped animals were classified, weighed, their sex determined, and finally they were sectioned in order to find out traces of coloured wool in the alimentary canal. The estimation of density of particular rodent species, taking into consideration the influence of trapping grid on adjoining areas, was carried out according to the method of Ryszkowski (1971), which depends on the comparison of places of capture of differently tagged individuals.

The density determinations were accomplished in a forest (102 ha) composed of three different tree stands typical for the study area. The first two stands of the forest consisted of well grown deciduous trees (oak and lime 90-year-old), coniferous trees (pine and spruce 70-year-old), while the third consisted of thickets and pole-sized stands (pine, spruce). An accurate description of the studied forest is given in a paper by Ryszkowski et al. (1971).

Altogether 15 series of trappings were carried out, during which 412 individuals of C. glareolus, 360 individuals of A. flavicollis and 230 individuals of $A$. agrarius were captured. The obtained values of density were extrapolated for the whole area of woods and forests. For the estimation of the number of present individuals 3 periods were distinguished, similarly to $M$. arvalis. During the two autumn-winter seasons no reproduction among forest rodents was ascertained (C. glareolus, A. flavicollis, A. agrarius). Hence the total number of rodents present in the autumn-winter period was determined by the autumn density, estimated after the end of the breeding period. For the vegetation period (1 April -31 October 1971) the total number of present individuals $(V)$ was estimated according to the method described for $M$. arvalis. The average length of life of $A$. flavicollis was taken as 90 days according to $\mathrm{B}$ o bek (1969). The same length of life was assumed also for A. agrarius. For the lack of information which of the habitats are occupied in summer by $A$. agra- 
rius no correct estimates of its density on the study area in this period could be made. For this reason the number of individual-days with corrections for the vegetation period was calculated only on the basis of the density determinations in spring and autumn. P u c e k, Rys zkow ski \& Z e jda (1969) estimated the mean longevity of C. glareolus in different forest associations. The forests in the neighbourhood of Turew correspond to the category of mixed forests distinguished by those authors in which the bank vole lives for 60 days on the average. This value was used for the calculations.

Table 4

Density of forest rodents in Turew Forest, individuals per ha, A. f. - Apodemus flavicollis, A. a. - Apodemus agrarius, C. g. - Clethrionomys glareolus.

\begin{tabular}{|c|c|c|c|c|c|c|}
\hline \multirow{2}{*}{ Habitat* } & \multirow{2}{*}{ Species } & \multicolumn{5}{|c|}{ Date of the beginning of trapping } \\
\hline & & 15.X.70 & 1.IV.71 & 15.VII.71 & 1.XI.71 & 15.IV.72 \\
\hline $\begin{array}{l}\text { Young } \\
\text { pinewood, } 36 \text { ha }\end{array}$ & $\begin{array}{l}\text { A. } f . \\
\text { A. } a . \\
\text { C. } g .\end{array}$ & $\begin{array}{r}14.3 \\
3.5 \\
28.0\end{array}$ & $\begin{array}{r}2.5 \\
0.3 \\
10.3\end{array}$ & $\begin{array}{r}0.6 \\
0.0 \\
13.7\end{array}$ & $\begin{array}{r}11.6 \\
5.6 \\
31.6\end{array}$ & $\begin{array}{r}4.9 \\
0.6 \\
12.3\end{array}$ \\
\hline Oak wood, 28 ha & $\begin{array}{l}\text { A. } f . \\
\text { A. } a . \\
\text { C. } g .\end{array}$ & $\begin{array}{l}9.4 \\
5.0 \\
0.4\end{array}$ & $\begin{array}{l}1.1 \\
0.0 \\
0.0\end{array}$ & $\begin{array}{l}0.1 \\
0.0 \\
0.0\end{array}$ & $\begin{array}{r}12.7 \\
16.8 \\
1.2\end{array}$ & $\begin{array}{l}3.0 \\
2.0 \\
2.3\end{array}$ \\
\hline Mixed forest, 38 ha & $\begin{array}{l}\text { A. } f . \\
\text { A. } a . \\
\text { C. } g .\end{array}$ & $\begin{array}{r}14.8 \\
5.1 \\
16.5\end{array}$ & $\begin{array}{l}2.7 \\
0.0 \\
7.3\end{array}$ & $\begin{array}{l}1.1 \\
0.0 \\
5.3\end{array}$ & $\begin{array}{r}89 \\
11.7 \\
24.8\end{array}$ & $\begin{array}{r}3.2 \\
0.3 \\
12.0\end{array}$ \\
\hline $\begin{array}{l}\text { Weighed mean for the } \\
\text { whole forest, } 102 \text { ha }\end{array}$ & $\begin{array}{l}\text { A. } f . \\
\text { A. } a . \\
\text { C. } g .\end{array}$ & $\begin{array}{r}13.1 \\
4.5 \\
16.1\end{array}$ & $\begin{array}{l}2.2 \\
0.1 \\
6.3\end{array}$ & $\begin{array}{l}0.6 \\
0.0 \\
6.8\end{array}$ & $\begin{array}{l}11.0 \\
11.0 \\
20.7\end{array}$ & $\begin{array}{l}3.7 \\
0.9 \\
9.4\end{array}$ \\
\hline All species jointly & & 33.7 & 8.6 & 7.4 & 42.7 & 13.0 \\
\hline
\end{tabular}

* In each habitat one series of trappings was carried out.

2.2.2. Results

Three species of forest rodents under question showed annual cycles in their numbers in distinction to $M$. arvalis, the density of which was increasing during the whole year 1971. The lowest density of forest rodents was observed in spring or summer. The individuals of A. agrarius were not trappable in summer 1971 (Table 4). A similar situation occurred in summer 1969 and 1970 (R y s z ow ski et al., 197i). This may indicate that in summer $A$. agrarius leaves the forest moving to other unknown types of habitats. In spring and summer 1971 the occurrence of this species in different plant cultures was ascertained during the estimation of $M$. arvalis density. The very inaccurate estimte of $A$. agrarius density obtained in this way amounted in the vegetation period to 
approximately one half of the individual per 1 ha of arable land. The highest density of A. agrarius occurred in autumn, similarly to the other two species. In distinction to $M$. arvalis the density of $C$. glareolus, $A$. flavicollis and A. agrarius practically remained constant in 1971. The total density of these three rodent species was in autumn 1971 higher by only $25 \%$ in comparison with autumn 1970 (Table 4). However, in the preceding year their numbers increased by 4 times. In autumn 1969 it

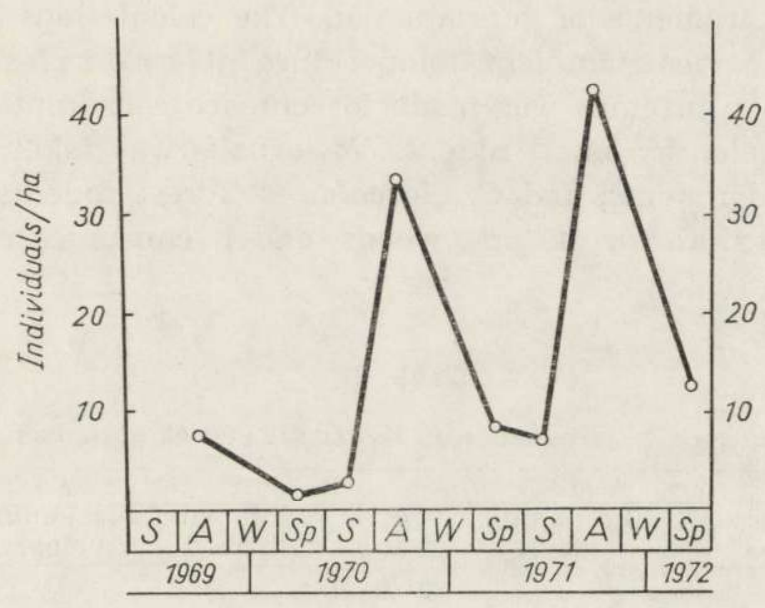

Fig. 2. Density of forest rodents per average forest habitat.

Table 5

Total number of forest rodents present.

\begin{tabular}{lccccc}
\hline & \multicolumn{5}{c}{ Period } \\
\cline { 2 - 6 } Species & 15 Oct. 19;0 & 1 April 1971 & 1 Nov. 1971 & 15 Oct. 1970 \\
& 31 March 71 & 31 Oct. 71 & 31 March 72 & 31 & March 72 \\
\hline A. flavicollis & 4,716 & 8,028 & 3,960 & 11,945 \\
A. agrarius & 1,620 & 8,302 & 3,960 & 9,896 \\
C. glareolus & 5,814 & 17,640 & 7,452 & 21,168 \\
Total & 12,150 & 33,970 & 15,372 & 43,009 \\
\hline
\end{tabular}

was found that the total density of these three species amounted to 7 individuals/ha (Ryszkowski et al., 1971), while in autumn 1970 their density exceeded 33 individuals/ha (Fig. 2). In the period of present investigations the total number of rodents present in forests was estimated as 43,000 (in the vegetation period almost 34,000 ). The Bank vole was the most abundant species (21,000 individuals, Table 5). 


\section{THE EFFECT OF RODENTS ON VEGETATION}

\subsection{Consumption of Plants}

\subsubsection{Method}

The amount of consumed plant biomass can be calculated from the estimates of daily energy budgets $(D E B)$. This budget includes energetic costs of animal metabolism taking into account daily rhythm of activity and energy requirements of reproduction. The calculations take also in consideration the mean ambient temperature (Grodzinski \& Gó$\mathrm{recki}$ 1967). An attempt was made to compare consumption of plants in forests and fields by small rodents. $M$. arvalis was taken as a representative of field rodents, and C. glareolus - forest rodents. The latter species is confined to forests and woods, and it consumes mainly plant food (P e trov, 1963).

Table 6

Daily food requirements of $M$. arvalis and C. glareolus.

\begin{tabular}{|c|c|c|c|c|c|c|}
\hline Species & Season & $\begin{array}{c}\text { A }(D E B)^{*} \\
\text { (kcal/anim. } \\
\text { /day) }\end{array}$ & $C / A^{* *}$ & $\begin{array}{c}C \\
\begin{array}{c}\text { (kcal/anim. } \\
\text { /day) }\end{array}\end{array}$ & $\begin{array}{c}F \\
\begin{array}{c}\text { (kcal/anim. } \\
\text { /day) }\end{array}\end{array}$ & $\begin{array}{c}U \\
\begin{array}{c}\text { (kcal/anim } \\
\text { /day) }\end{array}\end{array}$ \\
\hline \multirow{2}{*}{ M. arvalis } & $\begin{array}{l}\text { Autumn } \\
\text { Winter }\end{array}$ & 11.3 & \multirow{2}{*}{1.29} & 14.6 & 2.73 & 0.55 \\
\hline & $\begin{array}{l}\text { Spring } \\
\text { Summer }\end{array}$ & 8.4 & & 10.8 & 1.93 & 0.41 \\
\hline \multirow[t]{2}{*}{ C. glareolus } & $\begin{array}{l}\text { Autumn } \\
\text { Winter }\end{array}$ & 10.2 & \multirow[t]{2}{*}{1.15} & 11.7 & 1.38 & 0.24 \\
\hline & $\begin{array}{l}\text { Spring } \\
\text { Summer }\end{array}$ & 10.5 & & 12.1 & 1.43 & 0.25 \\
\hline
\end{tabular}

* Data for $M$. arvalis after Trojan (1969), for $C$. glareolus after Grodziński \& Górecki (1967).

** After Droż d ż (1969).

Utilizing the data of literature on the daily energy budget (DEB), and the ratio of assimilation to consumption, the daily consumption $(C)$ by these two species was calculated, jointly with the estimation of the amount of excreted feaces $(F)$, and urine $(U)$ (Table 6). In order to express in units of weight the amount of consumed plants one must divide consumption in calories by the mean caloric value of $1 \mathrm{~g}$ dry plant weight. This value amounts roughly to $4 \mathrm{kcal}$ for herbaceous plants (L i e th, 1968). 


\subsubsection{Results}

Taking into consideration the estimates of density for spring-summer 1970 given by Ryszkow ski et al. (1971) it was possible to determine consumption of plants by rodents during two consecutive years (1 April 1970 - 31 March 1972). The mass of consumed vegetation was calculated by multiplying the number of individual-days by daily consumption.

During the first year (1 April 1970 - 31 March 1971) the density of $M$. arvalis in alfa-alfa plantations amounted to 44 individuals per 1 ha, while mean density of $C$. glareolus in forests - to 6.3 individuals/ha (Table 7). In the second year (1 April 1971 - 31 March 1972) the mean density of $M$. arvalis in alfa-alfa cultures increased to 774 individuals/ha, and C. glareolus in forests only to 10.8 individuals/ha. The annual consumption of alfa-alfa by the individuals of $M$. arvalis increased from 79

Table 7

Consumption of plants by rodents in two consecutive years (per 1ha).

\begin{tabular}{|c|c|c|c|c|c|}
\hline \multirow{2}{*}{ Parameter } & \multirow[b]{2}{*}{ 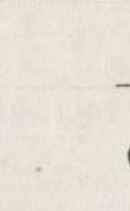 } & \multicolumn{2}{|c|}{$\begin{array}{l}\text { M. arvalis } \\
\text { /Alfa-alfa/ }\end{array}$} & \multicolumn{2}{|c|}{$\begin{array}{l}\text { C. glareolus } \\
\text { /Forest/ }\end{array}$} \\
\hline & & $\begin{array}{c}\text { First year } \\
\text { (1 April 70-31 } \\
\text { March 71) }\end{array}$ & $\begin{array}{c}\text { Second year } \\
\text { (1 April 71-31 } \\
\text { March 72) }\end{array}$ & $\begin{array}{c}\text { First year } \\
\text { (1 April 70-31 } \\
\text { March 71) }\end{array}$ & $\begin{array}{c}\text { Second year } \\
\text { (1 April } 71-31 \\
\text { March 72) }\end{array}$ \\
\hline \multirow{3}{*}{$\begin{array}{l}\text { Mean density } \\
\text { Consumption }\end{array}$} & per ha & 44 & 774 & 6.3 & 10.8 \\
\hline & kcal & 315,480 & $4,613,004$ & 33,283 & 55,330 \\
\hline & $g^{*}$ & 78,870 & $1,153,251$ & 8,321 & 13,842 \\
\hline \multirow[t]{2}{*}{ Feaces } & kcal & 58,995 & 862,632 & 3,927 & 6,592 \\
\hline & $\mathrm{g} * *$ & 13,408 & 196,052 & 893 & 1,499 \\
\hline Urine & kcal & 11,988 & 175,294 & 698 & 1,161 \\
\hline
\end{tabular}

* Assumed that $1 \mathrm{~g} \mathrm{d.w}$. of herbaceous plants has the value of $4 \mathrm{kcal}$ (Li e $\mathrm{t} \mathrm{h}, 1968$ ).

** In own determinations it was found that $1 \mathrm{~g} \mathrm{~d} . \mathrm{w}$. of feaces corresponds to 4.4. kcal.

to $1153 \mathrm{~kg}$ dry weight/ha. The amount of excreted feaces increased from 13 to $169 \mathrm{~kg}$ d.w. $/$ ha. The latter value, although it appears considerable, is in fact small in comparison with organic fertilizing. For example, fertilization with manure for root crops in the amount of $300 \mathrm{q} / \mathrm{ha}$ corresponds to approximately $8000 \mathrm{~kg}$ d.w./ha of the organic matter. Consumption of plants by $C$. glareolus was negligible in comparisen with $M$. arvalis and amounted in the first year to $8 \mathrm{~kg}$ d.w./ha (Table 7). In order to show trophic relationship of $M$. arvalis population on the whole study area consumption of vegetation from average acreage of cultivated land was calculated. For the computation of this mean value the estimates of rodent density in various plantations were taken into consideration. They were multiplied by the contribution of area of there plantations into the whole study area. In the year of mass appearance 
(1 April 1971 - 31 March 1972) the consumption amounted to $1,051,000$ $\mathrm{kcal} / \mathrm{ha}$ or $263 \mathrm{~kg}$ d.w./ha from the mean hectare of cultivated land. The amount of excreted feaces reached $169 \mathrm{kcal} / \mathrm{ha}$ or $38.5 \mathrm{~kg}$ d.w./ha, and urine $-39,900 \mathrm{kcal} / \mathrm{ha}$. The amount of consumed plant mass in alfa-alfa cultures (1153 kg d.w./ha) exceeded fourfold consumption from the average ha of cultivated land.

During feeding the rodents destroy vegetation. Cut but not consumed plants are used for the construction of nests, or are left in the field. In order to estimate the amount of destroyed plants in alfa-alfa cultures the following observations were carried out. On the area of $64 \mathrm{~m}^{2}$, surrounding a colony of common voles, stems of alfa-alfa were labelled with a dye, and their average density and biomass were calculated. After 10 days the number of removed stems and their biomass were estimated. During the observations cut stems lying on the pathways

Table 8

Estimation of losses caused by $M$. arvalis in alfa-alfa cultures.

\begin{tabular}{|c|c|c|c|c|c|}
\hline \multirow{3}{*}{ Parameters } & \multicolumn{5}{|c|}{ Succesive years } \\
\hline & \multicolumn{3}{|c|}{1 April $70-31$ March 71} & \multicolumn{2}{|c|}{1 April $71-31$ March 72} \\
\hline & $\mathrm{kg}$ & d.w./ha & $\begin{array}{c}\% \text { from potential } \\
\text { crop }\end{array}$ & kg d.w./ha & $\begin{array}{l}\% \text { from potential } \\
\text { crop }\end{array}$ \\
\hline Collected crop & & 9,600 & 98.6 & 7,600 & 78.6 \\
\hline Consumption & & 79 & 0.8 & 1,153 & 11.9 \\
\hline Destroyed plants & & 63 & 0.6 & 922 & 9.5 \\
\hline Potential crop & & 9,742 & 100.0 & 9,675 & 100.0 \\
\hline $\begin{array}{l}\text { Mean density, } \\
M \text {. arvalis }\end{array}$ & \multicolumn{3}{|r|}{44} & \multicolumn{2}{|r|}{774} \\
\hline
\end{tabular}

of voles were also collected. Afterwards the colony was flooded with water and the number of voles was determined. In such way three vole colonies were observed. The mass of removed stems amounted to $299.2 \mathrm{~g}$ d.w. Assuming that an individual consumed $10.8 \mathrm{kcal}$ daily on the average ( $\mathrm{Trojan} \mathrm{1969a)} \mathrm{-} \mathrm{the} \mathrm{total} \mathrm{consumption} \mathrm{of} \mathrm{six} \mathrm{indi-}$ viduals present in these colonies during 10 days amounted to $648 \mathrm{kcal}$ (or $162 \mathrm{~g} \mathrm{~d}$.w. of plants). The ration of the removed to consumed plant mass is thus 1.8 . Out of 137.2 of cut but not consumed plants 78.4 were found on pathways, and the remaining were probably taken into burrows.

Knowing the weight ration of cut and consumed plants the losses zaused by voles in alfa-alfa plantations during two years could be calculated. According to the data provided by the State Farm Turew the alfa-alfa crop collected in the vegetation period 1970 amounted to $9600 \mathrm{~kg}$ d.w./ha (480 q/ha), and in 1971 to $7600 \mathrm{~kg}$ d.w. per ha $(380 \mathrm{q} / \mathrm{ha})$. 
Consumption of alfa-alfa by field voles was equal to $79 \mathrm{~kg}$ d.w./ha in the first year and to $1153 \mathrm{~kg} \mathrm{d.w./ha}$ in the second year (Table 8). On the basis of estimated consumption the total mass of plants destroyed by voles was calculated by using the coefficient of 1.8. Then it was possible to calculate the biomass of cut but not consumed plants. The increase in vole density from 44 to 774 individuals per ha caused the increase of losses from 1.4 to $21.4 \%$ (Table 8). The losses were calculated in relation to the potential crop equal to the sum of collected crop and biomass of plants destroyed by voles. In these calculations the effect of other herbivorous animals, such as hares and roe-deer, was neglected. The ratio of consumed by voles plant biomass to potential crop amounted in the first year to $0.8 \%$ and in the second year to $11.9 \%$.

The damages caused by voles can be compensated by regrowth of plants. This occurs in the case of overwintering rye. In autumn and winter voles consume considerable amounts of rye stems, this fact being easily ascertained after a thaw. For example in spring 1972 it was found that

Table 9

Regrowth of rye after feeding of voles.

\begin{tabular}{|c|c|c|c|c|}
\hline \multirow[b]{2}{*}{ Parts of plants } & \multirow[b]{2}{*}{ Day } & \multicolumn{3}{|c|}{ Biomass of rye $\mathrm{g}$ d.w. $/ \mathrm{m}^{2}$ in the place } \\
\hline & & $\begin{array}{c}\text { Without } \\
\text { voles feeding }(a)\end{array}$ & $\begin{array}{c}\text { With } \\
\text { voles feeding }(b)\end{array}$ & $a: b$ \\
\hline Above-ground & 1 III & 91.2 & 25.9 & 3.5 \\
\hline Above-ground & $2 \mathrm{~V}$ & 441.9 & 251.3 & 1.7 \\
\hline Seeds & 27 VII & 318.0 & 313.0 & 1.0 \\
\hline Straw & 27 VII & 536.0 & 571.0 & 0.94 \\
\hline
\end{tabular}

the mean area of rye plantation destroyed by voles amounts to $6.8 \% \pm 1.2$ (the estimations were made in 6 different fields). Feeding of voles causes the reduction in the number of stems but without affecting the root system. According to $\mathrm{K} \mathrm{ukiel} \mathrm{ska}$ (personal communication) the mean biomass of rye in spring in the vicinity of a vole colony is on the average 3.5 times lower than in unaffected areas. At a time when rye begins to grow in haulm the ration of biomass of the above-ground parts in areas free of voles, to the biomass in areas affected by early spring consumption of voles, amounts to 1.7. However, during the harvest the effects of voles damages disappeared and the crop was not affected (Table 9). In the field where these observations were made the number of voles was the following: in autumn - 2, in spring - 21, and in summer -13 individuals per $1 \mathrm{ha}$. It is possible that at high density of voles in a period lasting for approximately 1.5 month after thawing of snow and before intense growth of rye stems a decrease in the crop 
would be perceptible. Overwintering wheat propagating intensely in spring reacts probably in a different manner than overwintering rye to feeding of rodents in winter.

\section{PRESSURE OF PREDATORS ON RODENTS}

\subsection{Methods and Way of Calculation}

The number of consumed individuals in a unit of time expresses the effect of predators on the population of prey. In order to estimate this value it is essential to know the numbers of predators, their feeding requirements and daily consumption of the prey.

\subsubsection{Numbers of Predators}

Different biology of studied species required the application of various methods for estimating their numbers. In autumn-winter season (when plants did not obscure observation) the estimations of the number of foxes and cats were carried out at night during a drive with a car equipped with an additional side search-light. The range of light marked the width of the observation field. The average length of the tour amounted to $10 \mathrm{~km}$, crosing all represented habitats. On the basis of observations the mean density of foxes and cats per $\mathrm{km}^{2}$ was estimated and the obtained values were extrapolated to the whole study area. In winter: numbers of foxes were additionally estimated from snow trails.

The density of martens (Martes martes and M. foina) was estimated jointly for both species of the basis of winter trackings.

In the vegetation period the numbers of badgers and foxes were estimated on the basis of observations of burrows. This enabled additionally to estimate the number of young animals.

The weasels were captured in live-traps with meat as a bait. On the area of 150 ha 30 traps were placed on the border of small woods, along irrigation canals and so on. The traps were inspected daily during a 2-week series of trappings. The captured animals were individually marked and released on the spot. The trappings were carried out in spring, summer, and early and late autumn. Altogether 26 weasels were captured. The estimation of density for each series of trappings was obtained by dividing the number of present individuals by the area in which the traps were set. The obtained results were extrapolated to the whole study area. They should be regarded as the minimum estimations of density of weasels. 
The numbers of three species of owls was estimated by reproducing their voices from a recorder tape. Owls belong to territorial animals reacting to voices of other individuals of the same species. A voice reproduced from the tape enabled the estimation of their density in forests and woods. The results were additionally compared with visual observations. Additionally for the estimation of the number of barn owls several buildings suitable for their nests were searched. In the case of tawny owl the number of nestlings was estimated from the observations of nest boxes (R y s z k ow ski et al., 1971).

In the spring-summer period the number of nesting pairs of buzzards (Buteo buteo) was estimated, and the number of young birds was determined during observations of a nest. Similarly to previous years (Ryszkowski et al., 1971) two nests were lowered, and covered by a screen, and the food brought by the parents to nestlings was analysed. During the migration period (October-- March) the number of buzzards (Buteo buteo and B. lagopus) was estimated by field census. At the same moment of time several observers registered the visible buzzards on the whole study area. Altogether seven censuses were carried out.

In the estimation of the number of bird and mammalian predators information obtained from the game wardens of the Hunting Station at Czempin was also utilized.

\subsubsection{Food Requirement of Predators}

Daily food requirements of young and adult foxes, adult martens and barn owls were established experimentally. The animals were supplied with a known amount of food and then by collecting and weighing the left residue the daily food requirement was evaluted.

$V$. vulpes. Food requirement of 4 growing foxes kept in a pen $(4 \times 4 \mathrm{~m})$ was determined. The experiment began when the individuals weighed ca $300 \mathrm{~g}$ (moment of eye opening), and was completed when they reached the weight of adults $(4$ to $5 \mathrm{~kg}$ ). The total amount of consumed food in the period of body weight increase divided by the length of this period corresponded to the mean daily requirement of young foxes. The amount of food consumed per day by 4 adult foxes was determined several times during 3-6 day experiments in autumn and winter. On account of lack of measurements in summer the determined values were applied for the whole year.

Martens ( $M$. martes and $M$. foina). Food requirements of $M$. foina (body weight $1.0 \mathrm{~kg}$ ) were established during two 5-day experiments. For $M$. martes (body weight $1.38 \mathrm{~kg}$ ) only one 5-day experiment was Acta theriol. 10 
carried out. The animals were kept in cages. Due to difficulties in the separation of these two species in the estimates of their numbers, and because it was impossible to distinguish their feaces, the mean value from the determinations of $M$. martes and $M$. foina was taken as daily requirements of martens. The amount of food consumed by young animals was taken after Szuman, Woliński \& Kulikowski (1955).

Tyto alba. Daily food requirement of two individuals (weighing approximately $300 \mathrm{~g}$ ) kept in cages was estimated in feeding experiments lasting 5 and 10 days in winter. It was assumed that the mean food requirement of young individuals amounts to $80 \%$ of that consumed in winter by adult individuals, as it was found in Strix aluco (R y s zk ow ski et al., 1971).

Table 10

Number of analysed bird-pellets and portions of feaces of predatory mammals.

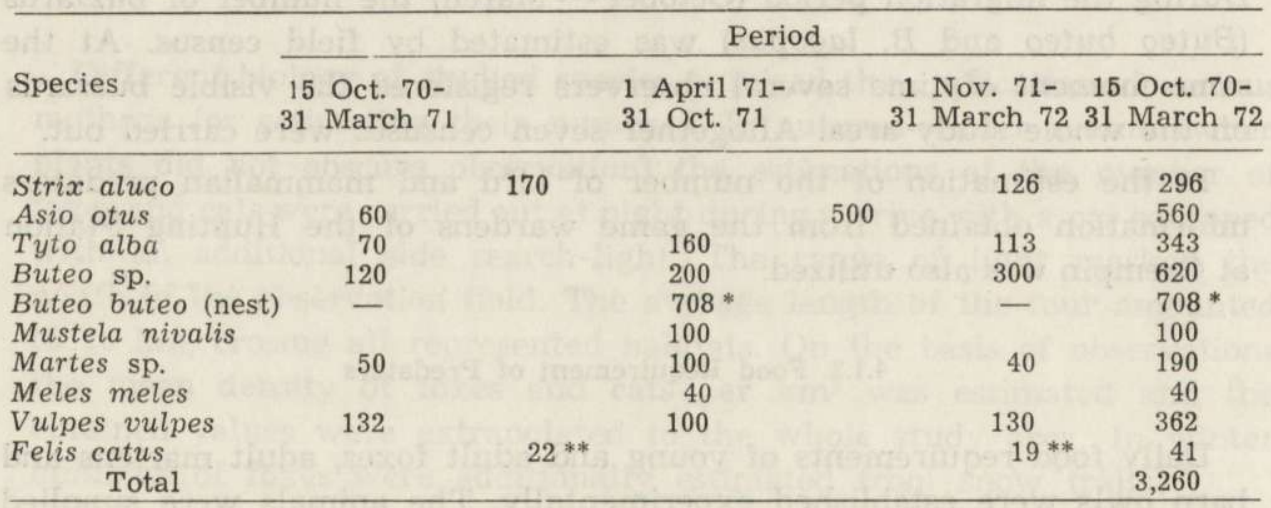

* Remnants of the food, ** Stomachs

Buteo buteo juv. The mean food requirement of young buzzards was calculated by dividing the weight of the food brought by the parents to five nests covered with a screen by the number of individual-days of young buzzards. Each nest was observed for approximately 30 days.

The amount of food consumed by adult buzzards and by adult individuals of Strix aluco was assumed from the experiments described by Ryszkowski et al. (1971).

Daily consumption by Asio otus was estimated on the basis of the values discussed by $\mathrm{Cz}$ a r ne cki (1956).

The food ration of $M$. nivalis was estimated after Heptner, Naumov, Jurgenson, Sludski, Čirkova \& Bannikov (1967) assuming that daily food intake equals $1 / 3$ of body weight. Since the mean body weight of animals captured into traps in the study area 
amounted to $90 \mathrm{~g}$, it was assumed that the daily food requirement of adult individuals equals $30 \mathrm{~g}$. The amount of food consumed by the young animals was taken from the data of Lockie \& East (1964).

\subsubsection{Estimation of Daily Consumption of Prey}

The composition of predators diet in natural condition was estimated on the basis of content analysis of bird pellets and mammal feaces. The number of analysed samples of bird pellets and feaces is shown in Table 10.

Direct estimates of the number of consumed rodents were obtained only in sections of shot cat stomachs ${ }^{2}$. Since some of the cats were shot probably soon after they had started hunting, the registered filling of their stomachs was lower than it might be after the end of hunting. For this reason the values higher than the mean were used in the calculations of average vole number consumed by cat per day. In the period between 15 October 1970 and 31 October 1971 the potential filling of cat stomachs amounted to 11 rodents, and in the period between 1 November and 31 March 1972 - to 8 rodents. These values were assumed as the mean number of rodents consumed daily by a cat.

The corresponding values for the badger were estimated by the indirect method described by Ryszkow ski et al. (1971). This method depends on the identification of prey after found remains in feaces and then on the determination of the average number of recovered rodents per one scat.

Then it was established in feeding experiments that one badger excretes daily two scats. Multiplying by two the found mean number of rodents per one portion of feaces the daily consumption of rodents by the badger was estimated.

The bird pellets collected in the whole study area were analysed in the laboratory. The remains (teeth, bones, fur, feathers, etc.) enabled identification of the prey. The biomass of prey of adult buzzards and owls was estimated by multiplying the number of consumed individuals by their mean body weight. Then contribution of consumed rodent biomass to the total prey biomass consumption was estimated i.e. the weight per cent of a rodent prey in the predator diet was estimated. On the basis of direct weight determinations of the food brought to the nests covered with a screen the weight per cent of rodents in the diet of young buzzards was estimated.

${ }^{2}$ The authors are grateful to Dr. Z. Pielowski for the help in collecting the material. 
The analyses of feaces of predator mammals carried out according to method of Lockie (1959) enabled the determination of the weight per cent of rodents in their diet. The method is based on the utilization of food digestibility coefficients, which are calculated from the comparison of the amount of supplied food and the weight of not-digested remains ${ }^{3}$. The biomass of the consumed prey can be obtained by multi-

Table 11

Changes in numbers of predators in the period of investigations (area of $31 \mathrm{~km}^{2}$ ).

\begin{tabular}{|c|c|c|c|c|}
\hline Species & $\begin{array}{l}15 \text { Oct. } 1970- \\
31 \text { March } 1971\end{array}$ & $\begin{array}{l}1 \text { April } 1971- \\
31 \text { Oct. } 1971\end{array}$ & $\begin{array}{r}1 \\
31\end{array}$ & $\begin{array}{l}\text { Nov. 1971- } \\
\text { March } 1972\end{array}$ \\
\hline Strix aluco & 14 & $14-18$ & & 13 \\
\hline Asio otus & 4 & 4 & & 6 \\
\hline Tyto alba & 6 & $6-10$ & & 10 \\
\hline Buteo sp. & 15 & $16-60$ & & 48 \\
\hline Mustela nivalis & $78-68$ & $68-207$ & & 121 \\
\hline Martes sp. & 7 & $7-14$ & & 8 \\
\hline Meles meles & 6 & 6 & & 6 \\
\hline Vulpes vulpes & 18 & $18-32$ & & 20 \\
\hline Felis catus & $0-6$ & $6-62$ & & $62-36$ \\
\hline
\end{tabular}

Table 12

Daily food requirement of predators (live weight, $\mathrm{g}$ ).

\begin{tabular}{lcrc}
\hline \multirow{2}{*}{ Species } & Winter & \multicolumn{2}{c}{ Vegetation season } \\
\cline { 3 - 4 } & & Adults & $\begin{array}{c}\text { Young } \\
\text { (during period of growth) }\end{array}$ \\
\hline Buteo buteo & 91.0 & 80.0 & 87.0 \\
Strix aluco & 57.1 & 51.0 & 45.9 \\
Tyto alba & 70.0 & 70.0 & 56.0 \\
Asio otus & 35.0 & 35.0 & - \\
Vulpes vulpes & 468.7 & 468.7 & 446.8 \\
Martes sp. & 189.6 & 189.6 & 150.8 \\
Mustela nivalis & 30.0 & 30.0 & 14.5 \\
\hline
\end{tabular}

plying the weight of undigested remnants found in feaces by the corresponding coefficients of digestibility.

The classification of consumed rodents as individuals belonging to $M$. arvalis, C. glareolus, A. flavicollis or A. agrarius species was carried out on the ground of frequency of occurrence of teeth in the analysed portions of feaces of predators. Knowing the number of predators and

3 The ration of consumed food weight to remains weight in the feaces is described as the coefficient of digestibility. According to Gos zczyns s i this coefficient amounts to 23 for mouse-like rodents, to $\mathbf{3 5}$ for birds, to 50 for hares and to 118 for roe-deer. 
their daily food requriement it was possible to calculate the biomass of rodents consumed daily. Dividing the biomass of definite rodent species by their mean body weight it was possible to estimate the number of consumed individuals.

The total consumption of the prey in the selected periods was obtained by multiplying daily consumption by the number of individual-days of predators.

\subsection{Results}

\subsubsection{Consumption of Rodents}

Despite a considerable increase in the density of $M$. arvalis the numbers of predators in three distinguished periods did not show significant changes, except a marked increase in the number of cats and buzzards in autumn and winter 1971/72 (Table 11). The increase in the number of buzzards ( $B$. buteo and B. lagopus) was almost fourfold, and of cats - tenfold, in comparison with autumn 1970.

Daily food requirement of the investigated species of predators ranged from $30 \mathrm{~g}$ of live weight (Mustela nivalis) to $468.7 \mathrm{~g}$ of live weight (Vulpes vulpes) (Table 12).

Jointly all analysed predators consumed in the whole period of investigations 560,100 common voles (Table 13) and 16,900 mice and Bank voles (Table 14). The highest number of individuals of $M$. arvalis was consumed by foxes. The second place is occupied by cats, the third by weasels and fourth by buzzards (Table 13). Bank voles and mice were consumed the most frequently by martens and foxes (Table 14).

\subsubsection{Reaction of Predators to Incieased Number of $M$. arvalis}

Due to the fact that estimates of rodent density were simultaneously carried out in different habitats the effects of migration on changes of the rodent numbers in the whole area can be eliminated.

The difference between the number of rodents present in a given period of investigations and the ascertained end state can be used as a measure of general mortality of individuals. Comparing the number of rodents consumed by predators with the estimates of mortality the pressure of predators and its share in the total mortality of the population can be estimated. Despite increasing numbers of $M$. arvalis the share of predators in the general mortality decreased during the investigations. In autumn and winter 1970/71 the percentage of field voles consumed by predators amounted to $78.7 \%$ of total their mortality, and 


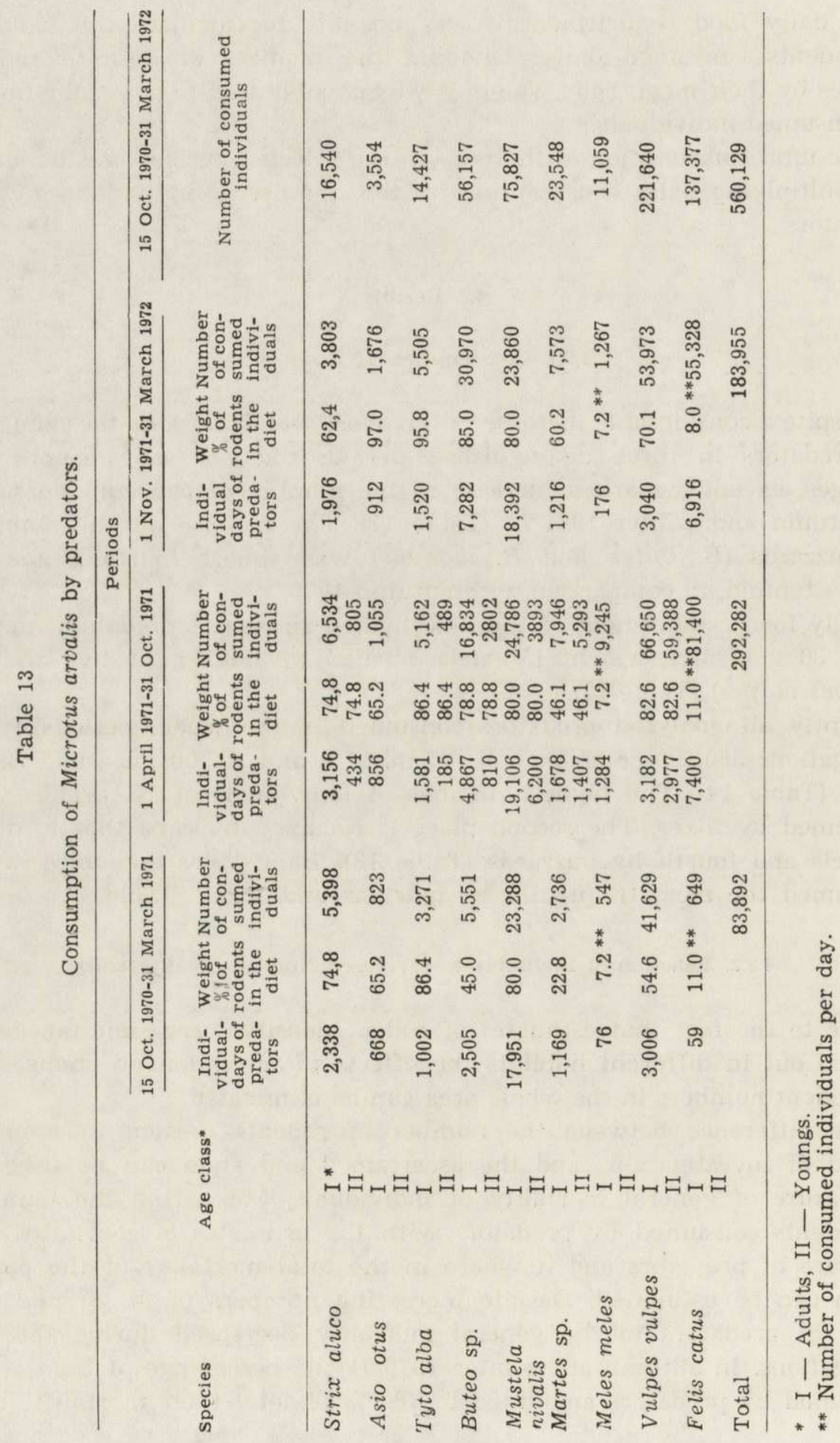




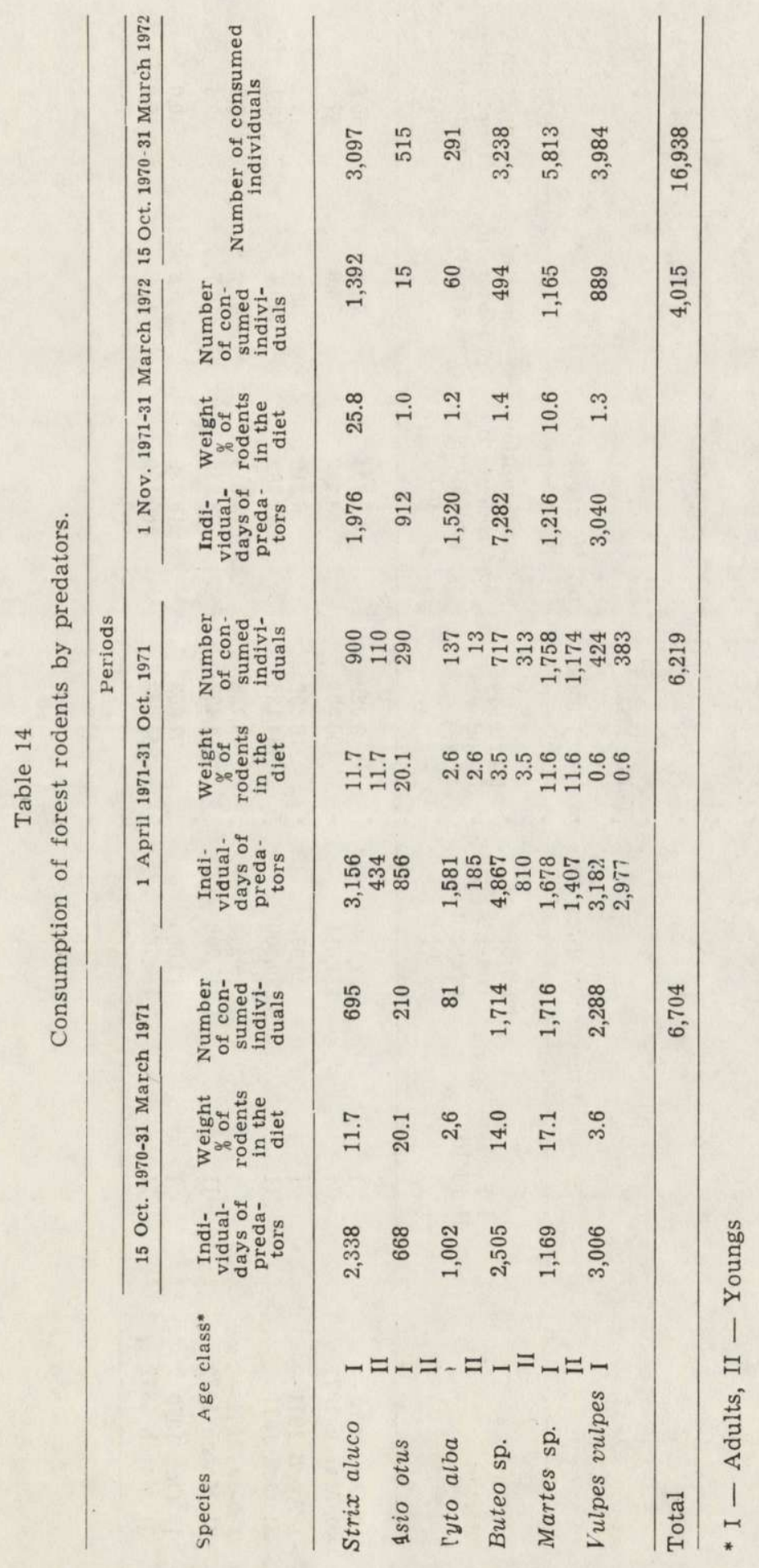




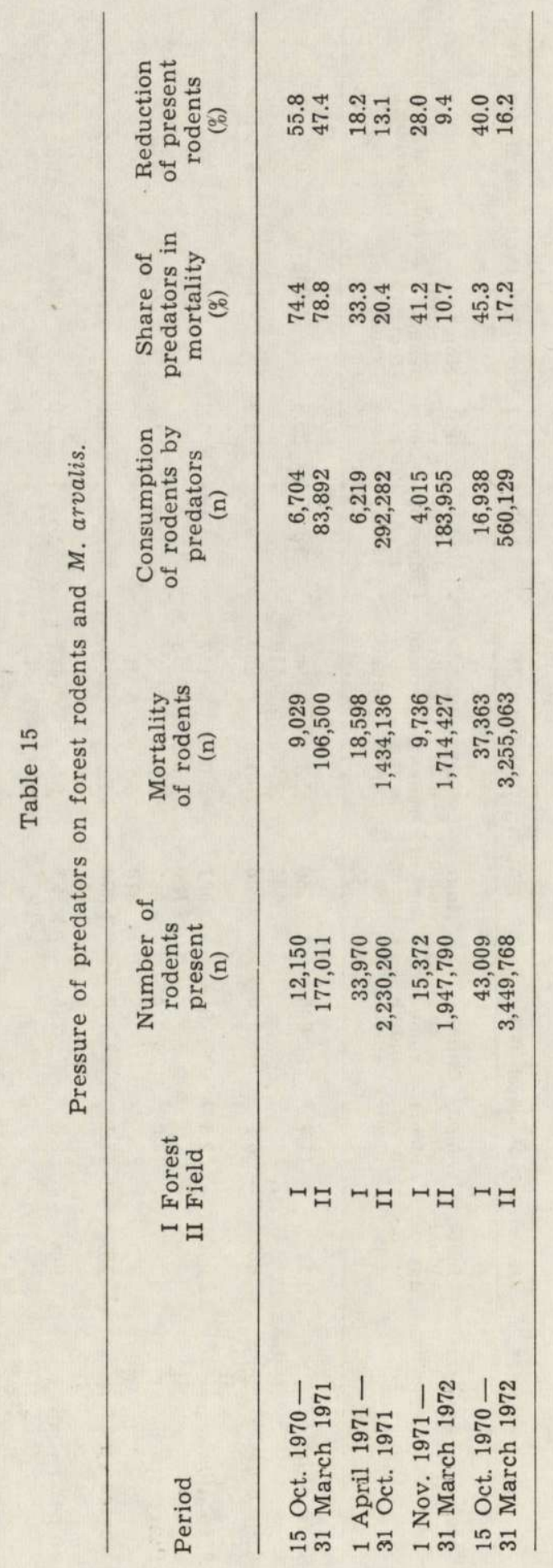


in the same period of the next year it fell to $10.8 \%$, or sevenfold. In the vegetation period this ratio amounted to $20 \%$ (Table 15). The degree of reduction of $M$. arvalis population by predators calculated from the ratio of individuals consumed to all present in a given period decreased five times (from $47.3 \%$ in winter $1970 / 71$ to $9.4 \%$ in winter 1971/72). This indicated increasing intensity of some others, not investigated here, factors of mortality in the population of $M$. arvalis.

A degree of reduction of forest rodents by predators, as well as the share of predators pressure in total mortality of these rodents, decreased only twofold in two consecutive winter periods (Table 15). Similarity of changes of these two indices suggests that the mortality associated with other factors than predators did not increase. In this situation a smaller pressure of predators results in a longer survival among forest rodents. It can be supposed that abundance of other prey in the form of $M$. arvaiis augments the chances of survival of forest rodents.

The reaction of predators to changes in the numbers of prey may be twofold (Solom on, 1949). With the increased abundance of prey the predators change their diet and consume a higher number of individuals of a given species. This constitutes a functional reaction of predators to the increased numbers of prey ( $\mathrm{S}$ olomon, 1949). On the other hand, the abundance of prey may be followed by an increased number of predators, and this represents a numerical reaction (S o l o m o $\mathrm{n}, 1949$ ).

Changes in the weight per cent of a given prey species in the predators diet represent a measure of the functional reaction. Utilizing the published materials on the share of $M$. arvalis in the predators diet at a low density of this species (R yszkowski et al., 1971), changes of this parameter were analysed in the period from the lowest to the highest density of common voles.

The mean weight percentage of $M$. arvalis in the diet of different predators was calculated. From winter 1969/70 to winter 1971/72 a continuous increase of the share of $M$. arvalis in the predators diet occurred (Fig. 3). In winter $1971 / 72 \mathrm{M}$. arvalis constituted almost $80 \%$ of weight in the mean diet or predators. At the same time a decrease in the coefficient of variation (ratio of standard deviation to mean, $\delta: \bar{x}$ ) for the share of $M$. arvalis in predator diet occurred (Fig. 3). This means that at high number of $M$. arvalis both the increase and levelling of the share of this species in the diet of various predators is observed.

Functional reactions of particular predator species are of course different. Martens (Martes sp.) hunting mainly in the fields adjoining to forests and woods began to consume more common voles only in spring 1971 (Fig. 4). 


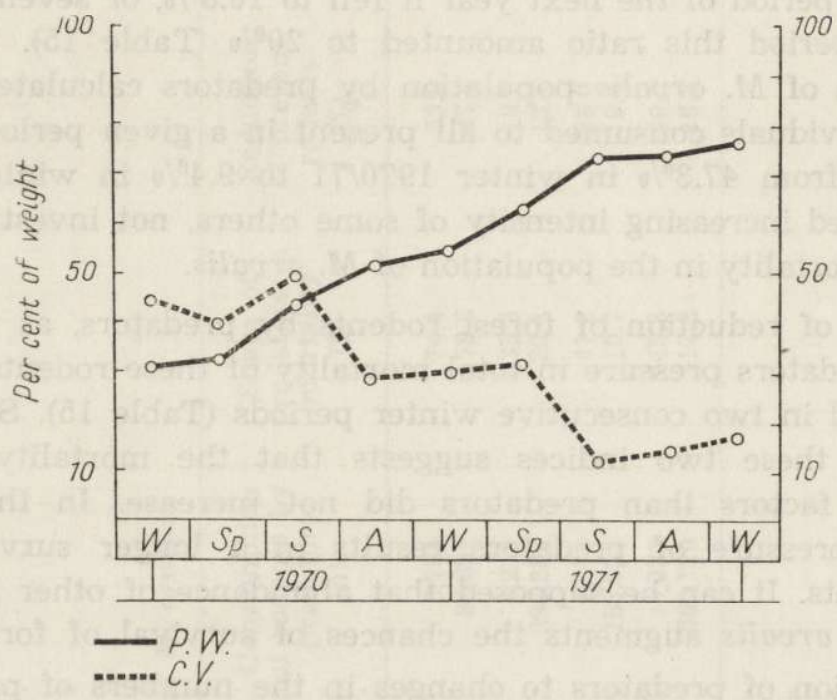

Fig. 3. Percentage of $M$. arvalis weight (P. W.) in predator diets. C.V. - coefficient of variation.

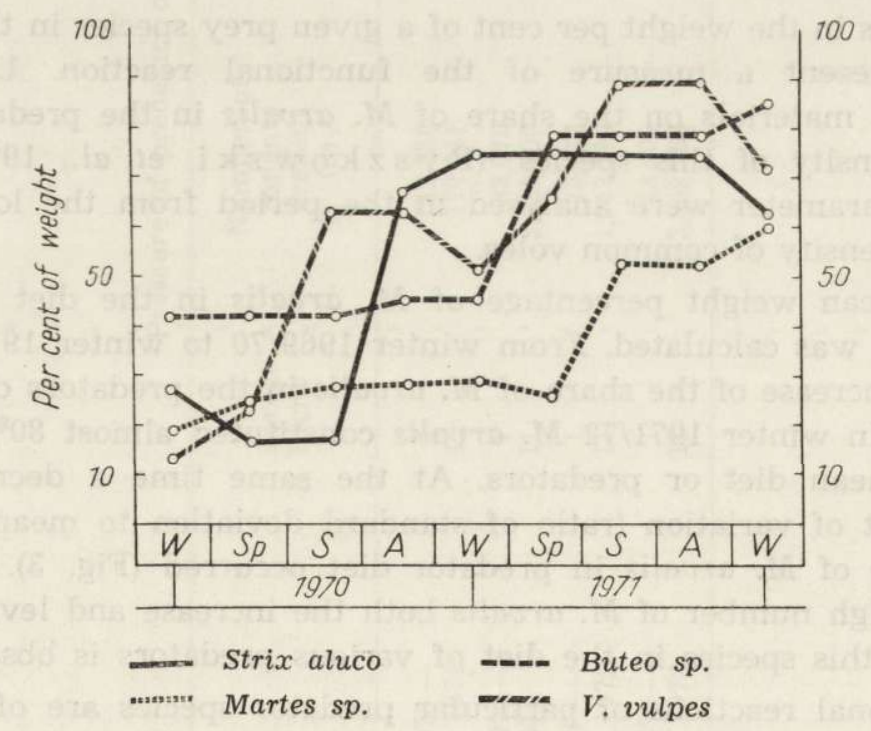

Fig. 4. Change of prey weight percentage in some predator diets. 
Strix aluco looking out for prey from trees, poles, and the like, changed its diet to $M$. arvalis in summer 1970. Despite further increase in the numbers of $M$. arvalis the weight percentage of voles in the diet of Strix aluco remained constant, and even showed a slight drop during the last winter (Fig. 4). This indicates that after some threshhold is overcome the availability of $M$. arvalis to Strix aluco did not change within the range of hunting area of tawny owl despite a general rise in the common vole population. Buzzards (Buteo sp.) hunting mainly on open space reacted to increased numbers of $M$. arvalis only in winter $1970 / 71$ (Fig. 4). During the whole next year the share of $M$. arvalis in the buzzard diet was high and ranged from 79 to $85 \%$. In the breeding period of buzzards comparison of body weights of common voles brought

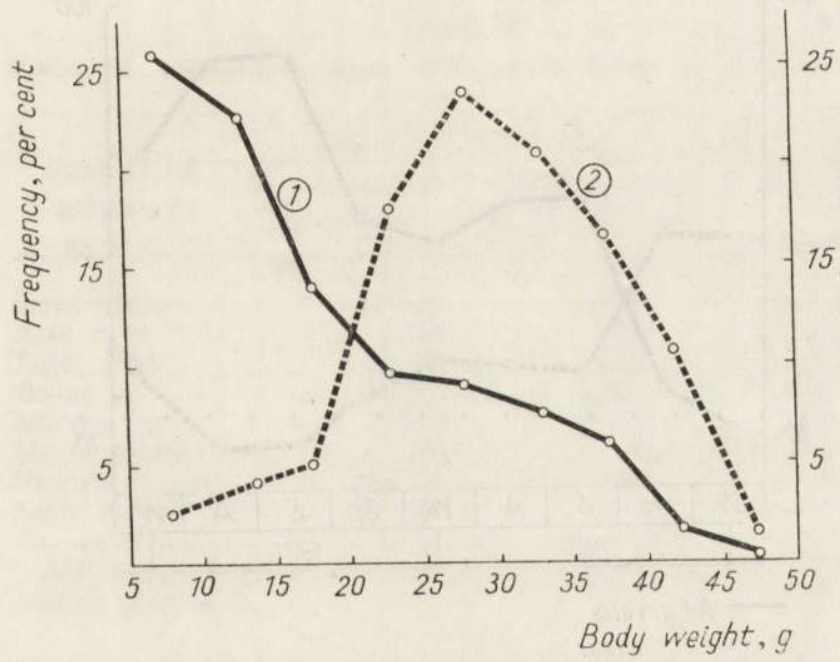

Fig. 5. Frequency distribution of the body weight of $M$. arvalis in cultivated fields (1) and of that caught by $B$. buteo (2) $\left(N_{1}=2132, N_{2}=436\right)$.

to nests with the weight of individuals occurring in plantations (flooding of burrows) demonstrated a considerable selection of heavy individuals (Fig. 5).

The share of $M$. arvalis in the diet of Vulpes vulpes increased gradually in parallel with voles density, although in winter a decrease was observed (Fig. 6). The rise of $M$. arvalis in the diet is accompanied by a decrease in the proportion of hares (Fig. 6). Parhaps in winter the availability of hares to foxes increases, e.g. due to other mortality factors the number of dead hares rises, and this leads to reduced hunting for voles. Other interpretations are also possible, e.g. lower availability of voles (snow cover) causes changes in the fox diet. 
The analysis of share of $M$. arvalis in the diet of these four groups of predators indicates, that availability of voles is different for various predators. The causes of these variations are not known accurately.

In respect of numerical reaction of predators to the mass outbreak of $M$. arvalis only small changes were observed, except of buzzards and cats. From the comparison of predators numbers in winter 1971/72 and winter 1970/71 (Table 11) it appears that a slight increase was observed for Asio otus, Tyto alba and Mustela nivalis. The numbers of Strix aluco, Martes sp., M. meles and V. vulpes did not change. The rise in the numbers of buzzards in autumn-winter season 1971/72 resulted from stopping in the study area some of the migrating individuals of $B$. buteo and $B$. lagopus. The mean number of present buzzards amounted in

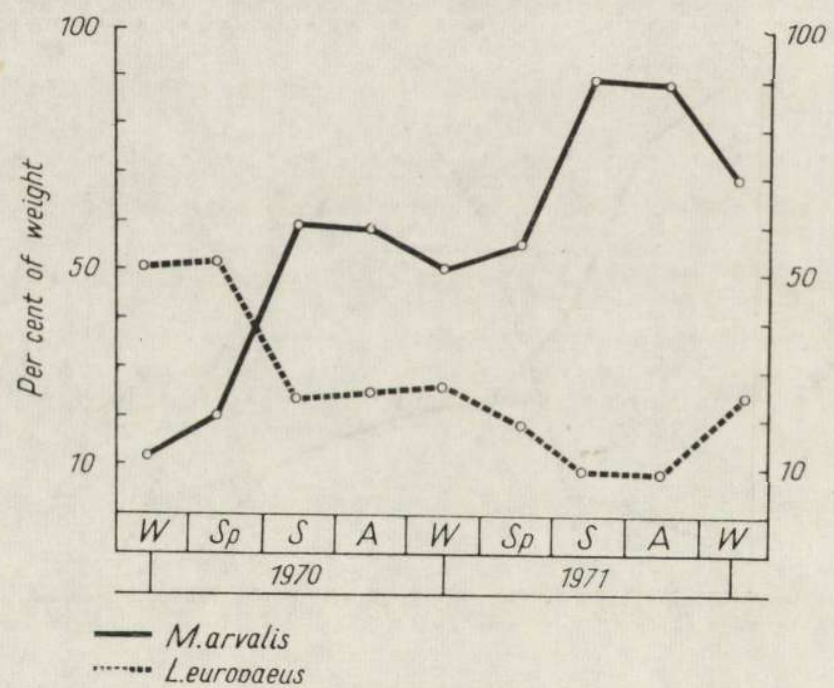

Fig. 6. Percentage of $M$. arvalis and $L$. europaeus weight in fox diets.

that period to 48 individuals in comparison with 15 in the same period of the previous year (Table 11). With the increased density of $M$. arvalis a higher number of cats moved from farms to plantations. The change in the occurrence of cats in the fields was the strongest numerical reaction among the examined predators during the whole period of studies (Table 11). This indicates that cats play an important, and hitherto not appreciated, role in the reduction of the numbers of field rodents.

However, despite conspicuous functional and some numerical reactions of predators to increased numbers of $M$. arvalis the reduction of rodents caused by predators was lower in years of mass occurrence than at low numbers of rodents. 
The mean reduction for the whole period of investigations amounts for $M$. arvalis to $16.2 \%$, and for forest rodents to $40 \%$ (Table 15).

\subsubsection{Penetration of Habitats by Predators}

Woods and crop plantations form a mosaic of various types of habitats. Large hunting areas of predators include generally all categories of habitats. It is likely that martens living in forests and woods represent a predatory mammal associated predominantly with only one type of habitat. Their hunting areas estimated by winter trackings include forests, woods and adjoining zones of plantations. This is confirmed by the highest share of forest rodents $(24 \%)$ in the their diet in comparison vith other predators.

Table 16

Ratio of consumed mice and bank voles to field voles.

\begin{tabular}{|c|c|c|c|}
\hline $\begin{array}{l}\text { Species of } \\
\text { predator }\end{array}$ & $\begin{array}{l}\text { (a) } \\
\text { Consumption } \\
\text { M. arvalis }\end{array}$ & $\begin{array}{l}\text { (b) } \\
\text { Consumption } \\
\text { A. sp.+C. } g .^{*}\end{array}$ & $b: a \times 100 \%$ \\
\hline Strix aluco & 16,540 & 3,097 & 18.7 \\
\hline Asio otus & 3,554 & 515 & 14.5 \\
\hline Tyto alba & 14,427 & 291 & 2.0 \\
\hline Buteo sp. & 56,157 & 3,238 & 5.8 \\
\hline Martes sp. & 23,548 & 5,813 & 24.7 \\
\hline Meles meles & 11,059 & 0 & 0.0 \\
\hline Vulpes vulpes & 221,640 & 3,984 & 1.8 \\
\hline Felis catus & 137,377 & 0 & 0.0 \\
\hline
\end{tabular}

* All representatives of the genus Apodemus plus Clethrio. nomys glareolus.

M. males pentrates both fields and forests searching for plant and animal food. In the period of studies Bank voles and mice were not found in the diet of badgers (Table 16). Weasels hunt both in woods and plantations. In winter their trails often lead from woods to stacks standing in fields. Cats hunt on different plantations in the vicinity of farm buildings but are not encountered in woods and forests. This was confirmed by the lack of Bank voles in the stomach content of shot cats. Considerable snow cover greatly reduces hunting activity of cats.

In order to investigate the intensity of penetration of various habitats by foxes approximately 200 observatory plots, each having 1 ha in area, were investigated in winter $1970 / 71$ and 1971/72. The length of track, frequency of burrowing and defecation for the mean acreage of a definite habitat was determined. During the two winters the highest number of traces of foxes activity was found in alfa-alfa plantations and meadows 
(Table 17). A considerable length of of tracks per one ha of forests is associated mainly with the places of shelter of foxes (burrows), as indicated by very small frequency of attempted hunting (burrowing in snow, Table 17). Relatively high activity of foxes in rape plantations (Table 17) is probably also associated with higher number of common voles in these cultures. Comparing the proportion of observed attempted huntings (burrowing in snow, spilled blood, etc.) in various habitats it can ke stated that in winter $1970 / 71$ foxes confined $75 \%$ of their

Table 17

Intensity of penetration of various forms of habitats by foxes (per day per 1 ha)

\begin{tabular}{|c|c|c|c|c|c|c|c|c|}
\hline \multirow[t]{2}{*}{ Habitat } & \multicolumn{2}{|c|}{$\begin{array}{l}\text { Length of trail, } \\
\text { m }\end{array}$} & \multicolumn{4}{|c|}{$\begin{array}{c}\text { Burrowing in Traces of urine. } \\
\text { snow, } \mathrm{n}\end{array}$} & \multicolumn{2}{|c|}{ Feaces, n } \\
\hline & 1971 & 1972 & 1971 & 1972 & 1971 & 1972 & 1971 & 1972 \\
\hline Ploughed fields & 52.8 & 45.4 & 0.07 & 0.2 & 0.04 & 0.3 & 0.035 & - \\
\hline Rape & 89.2 & $2: 6.0$ & 0.101 & 1.4 & 0.1 & 0.2 & - & - \\
\hline Overwintering & 64.5 & 76.0 & 0.147 & 0.32 & 0.04 & 0.2 & 0.022 & 0.03 \\
\hline Alfa-alfa & 173.0 & 220.0 & 1.176 & 2.47 & 0.39 & 0.6 & 0.052 & 0.17 \\
\hline Meadows & 288.0 & 236.0 & 1.441 & 1.15 & 0.53 & 0.66 & 0.21 & 0.3 \\
\hline Forest and woods & 136.0 & 150.0 & 0.06 & 0.14 & 0.22 & 0.6 & 0.056 & 0.02 \\
\hline
\end{tabular}

Table 18

Intensity of capture of rodents by foxes in various habitats (wintex).

\begin{tabular}{lrrr}
\hline \multicolumn{1}{c}{ Habitat } & & \multicolumn{2}{c}{ Removal $\%$} \\
\hline Ploughed fields & $\%$ of area & $1970 / 71$ & $1971 / 72$ \\
\cline { 3 - 4 } Rape & & 7.4 & 13.2 \\
Overwintering & 33.9 & 0.7 & 20.3 \\
Mlfa-alfa, & 2.3 & 15.3 & 31.1 \\
Feadows & 33.4 & 23.9 & 25.1 \\
Total and woods & 6.5 & 50.4 & 3.4 \\
Coefficient of variation & 11.2 & 2.4 & 100.1 \\
\hline
\end{tabular}

hunting activity to meadows and alfa-alfa cultures, which on the other hand constituted barely $17.7 \%$ of the whole study area (Table 18). In winter $1971 / 7256 \%$ of foxes activity was limited to meadows and alfa-alfa plantations. With the increase of total density of rodents in the whole study area the degree of differentiation of hunting activity of foxes in various types of habitats was reduced (comparison of the ratio of $\delta$ to the mean $\overline{\mathrm{x}}$ frequency of huntings in the two analysed winters, Table 18). 
Similarly to foxes also cats and buzzards limited their hunting activity mainly to the areas of high density of rodents (Table 19).

Among the analysed species of owls $S$. aluco and $A$. otus utilize in their diet more Bank voles and mice than T. alba (Table 16). Probably $T$. alba hunts mainly in the plantations adjoining buildings. S. aluco and $A$. otus look for the prey from trees in forest or stacks in the fields. The share of Bank voles and mice in their diet is high and similar to that in the diet of martens.

\section{TROPHIC RELATIONSHIP OF M. ARVALIS POPULATION}

Due to considerable changes in numbers the population of $M$. arvalis affects the web of trophic relationships in agrocenoses. During two years the amount of organic matter reaching the soil in alfa-alfa plantation in effect of activity of common voles (cut but not consumed parts of plants, feaces and urine) increased by almost 15 times (from

Table 19

Penetration of terrain by predators (number of individuals hunting in a given plantation).

\begin{tabular}{|c|c|c|c|c|c|c|}
\hline & \multicolumn{2}{|c|}{ Autumn 1971} & \multicolumn{3}{|c|}{ Winter, early spring 1972} & \multirow[b]{2}{*}{ Total } \\
\hline & Cat & Fox & Cat & Fox & $\begin{array}{c}\text { Common } \\
\text { buzzard }\end{array}$ & \\
\hline Alfa-alfa & 6 & 5 & 11 & 5 & 4 & 31 \\
\hline Meadows & 1 & - & 3 & - & 5 & 9 \\
\hline Overwintering & 4 & 1 & 4 & 2 & 12 & 23 \\
\hline Ploughed fields & 1 & 1 & 2 & - & - & 4 \\
\hline
\end{tabular}

$323 \mathrm{Mcal} / \mathrm{ha}$ to $4726 \mathrm{Mcal} / \mathrm{ha})$. The indirect effect of voles on saprophytic organisms was much higher than of other investigated rodent species. Due to changes in the number of voles there occurred clear functional reactions among predators feeding on them. Moreover, among some predator species also numerical reactions occurred. Such situation caused the reduction of mortality depending on these predators among forest rodents and hares. In the categories of field economy the mass occurrence of rodents was reflected in the fall of alfa-alfa crop. Moreover, in effect of autumn-winter damages caused by voles same plantations of alfa-alfa and wheat were ploughed in spring 1972 as being not suitable for further cultivation.

In order to depict trophic relationships of $M$. arvalis a scheme is presented (Fig. 7), showing this part of energy flow through agrocenoses, in which common voles play an important role. The scheme construction is based on the mean values of energy flow parameters for the investi- 
SOLAR ENERGY ABSORBED BY PLANTS $4520000 \mathrm{Mcal} / \mathrm{ha} / \mathrm{yr}$

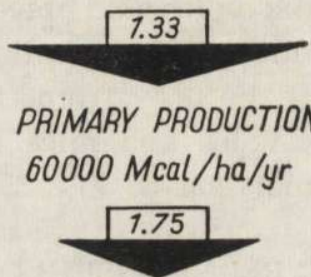

PLANT CONSUMPTION BY M.arvalis

/HIGH DENSITY YEAR/

$1051 \mathrm{Mcal} / \mathrm{ha} / \mathrm{yr}$

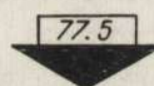

ASSIMILATION

814.5 Mcal/ha/yr

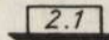

NET PRODUCTION

$17.1 \mathrm{Mcal} / \mathrm{ha} / \mathrm{yr}$

30.6

TOTAL CONSUMPTION BY PREDATORS

$5.3 \mathrm{Mcal} / \mathrm{ha} / \mathrm{yr}$

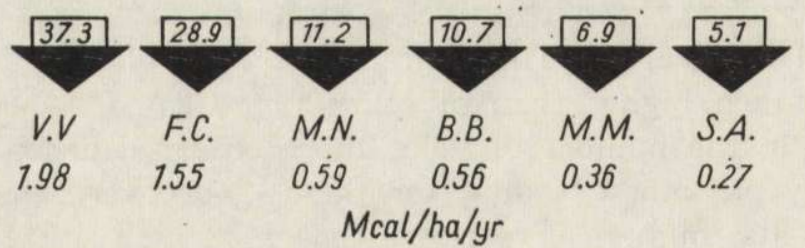

Fig. 7. Trophic relationships of $M$. arvalis.

V. V. Vulpes vulpes, F. C. Felis catus, M. N. Mustela nivalis, B. B. Buteo sp., M. M. Martes sp., Meles meles, S. A. Strix aluco, Asio otus, 'Tyto alba.

Numbers at arrows express percentages.

gated agricultural landscape in the year of mass occurrence of voles. Only the estimate of solar radiation derives from the studies of A. K amiński (unpubl. data from the Department of Agroecology, Polish Academy of Sciences) carried out in 1970 by means of a thermoelectric piranometer P $3 \times 3$ (energy delivered) and albedometer AP $3 \times 3$ (energ. 
radiated out). The mean caloric value of the net primary production calculated on the basis of materials provided by $\mathrm{Kukielska}$ (pers. comm.) amounted to $60,000 \mathrm{Mcal} / \mathrm{ha} /$ year $(15,000 \mathrm{~kg}$ d.m./ha). The calculations of total primary production of the above-ground and under-ground parts were made for two fields with a culture of rye and potatoes. The energy value of the primary production in relation to the energy absorbed by plants was found to be $1.33 \%$. This value is in agreement with many other estimates of photosynthesis efficiency in different plant associations ( $\mathrm{O} \mathrm{dum}, 1971)$, and thus it was assumed as the mean value for all plantations in the study area. On the basis of studies on the ratio of energy assimilated by rodents to energy accumulated in the net production, reviewed by $\mathrm{Ryszkowski} \& \mathrm{Pe}$ trusewicz (1967) and Grodziński, B obek, Drożd ż \& Gó$\mathrm{recki}$ (1969), it was assumed that this ratio amounts to $2.1 \%$. The calculated consumption by voles for the mean ha of plant cultures was equal to $1051 \mathrm{Mcal} / \mathrm{year}$. After subtracting the caloric value of excreted feaces and urine the estimate of assimilated energy was obtained (814.5 Mcal/ha/year). Hence the production of $M$. arvalis population amounted to $17.1 \mathrm{Mcal} / \mathrm{ha} /$ year (Fig. 7). This value depicts the potential amount of food available for predators. The pressure of all predators on $M$. arvalis expressed in energy units amounted to $30.6 \%$ (Fig. 7). The highest effect of the reduction of $M$. arvalis numbers was exerted by foxes, then by cats, and the third place was occupied by weasels.

Golley (1960) analysed the flow of energy through a food chain consisting of the primary production of an abandoned field, population of Microtus pensylvanicus pensylvanicus ( $\mathrm{Ord}$ ) and their predator Mustela rixosa allegheniensis ( $\mathrm{R} \mathrm{h}$ o a d s). The pressure of weasels on voles amounted to $31 \%$ in Golle y's investigations, while the corresponding value from our studies is $11.2 \%$. On the other hand, the degree of consumption of primary production by voles was similar: $1.6 \%$ according to Golle y (1960) and $1.75 \%$ in our investigations. These estimates were made for the year of mas occurrence of voles. Despite this fact the total pressure of predators according to our observations is similar to the pressure exerted in Golley's study by a population of weasels only.

\section{DISCUSSION}

The investigations presented here permit to estimate in general the function of $M$. arvalis in trophic relationships of the agricultural landscape. It is known that the population of this species shows cyclic changes in numbers (E l to n, 1942; $\mathrm{Frank}, 1957$; $\mathrm{B}$ a š e $\mathrm{n}$ in a, 1962). These changes were also observed on the study area where after some years Acta theriol. 11 
of low vole density in $1969 / 70$ ( $\mathrm{Ryszkowski}$ et al., 1971) the outbreak was observed in summer and autumn 1971. During these three years numbers of $M$. arvalis increased by almost hundred times. A trend of increase of forest rodents was also observed in this period, but their density augmented only sevenfold. Also in the geographical scale the smaller amplitude and higher irregularity of cycles were observed in animals inhabiting forests in comparison with the species from open habitats, e.g. S i iv o ne n (1948). In spring 1972 the eightfold decrease in the numbers of common vole was observed in relation to the peak density in 1971. This occurred despite persisted reproduction of these animals during the two winters. It is known, however, that drastic reductions in the population density of this species may take place independently of the reproduction occurrence or its lack ( $\mathrm{C} \mathrm{h} \mathrm{i} \mathrm{t} \mathrm{t} \mathrm{y,} \mathrm{1957).}$

Considerable changes in numbers of $M$. arvalis population affect the size of damages caused by them. It should be remembered however, that damages reflect not only consumption of plant by voles but also utilization of some plant parts for nest making, or scattering non-consumed fragments within a colony. This material and feaces of the animals constitute the source of food for various saprophagic organisms in the ecosystem. The ratio of total weight of plants removed from a field of alfa-alfa to the amount consumed was found to be 1.8:1 according to our estimates. The increasing density of voles reduced the crop of alfa-alfa by $100 \mathrm{q} / \mathrm{ha}$ on the average. The ratio of consumed plants to the potential crop amounted to $0.8 \%$ at the density of 44 individuals/ha, and to $11.9 \%$ at 774 individuals/ha in the second year. Identical estimates for the low density of voles ( 50 individuals/ha) were obtained by $\mathrm{Trojan}(1969 \mathrm{~b})$, according to whom the ratio of consumption to alfa-alfa crop was $0.8 \%$. In natural environment of a similar character (mountain meadow) $\mathrm{Gr}$ odziński, Górecki, Janas \& Migula (1966) estimated as $1 \%$ the ratio of consumption to crop of hay at a mean density (15 individuals/ /ha) of Microtus agrestis, (Linnae us, 1761) and Pitymys subterraneus (de Sélys-Long champs, 1835). The damages caused by mass appearance of $M$. arvalis were described several times, with quantitative estimation of losses (e.g. comprehensive reviews: El to n, 1942; Kratochvíl, 1959; B ašenina, 1962; M a ximov, 1964), but different methods used in these studies make difficult any comparison. The cases of total destruction of cultures cited by these authors were also partially confirmed by us in the study area. Some fiélds of alfa-alfa and wheat had to be ploughed in spring 1972 because their further utilization would be not profitable.

According to $\mathrm{Kr}$ a to chvil (1959) the intensivity in the damaging activity of rodents to overwintering crops is important in two periods. In 
the first one (immediately after sowing) the voles can consume all grains and farmers are compelled to repeat sowing. The second period occurs in early spring during intense growth of overwintering crops. $\mathrm{Kr}$ a toch víl (1959) reported that in Czechoslovakia damages caused by voles in cultures of overwintering rye are quite common.

Our investigations draw attention to a possibility of compensation of these damages by regrowth of plants. It was concluded that at low densities of voles damages caused by their feeding in winter-spring period, when the plants have already well developed root system, may not affect the expected crop.

It was demonstrated that voles inhabit very unevenly different cultures and are most numerous in plantations of perennial plants. In the period of investigations no vole colony was observed in root crops and maize cultures. Also in Czechoslovakia these cultures are rarely inhabited by voles ( $\mathrm{Kratochvil,} \mathrm{1959).} \mathrm{Hence,} \mathrm{when} \mathrm{estimating} \mathrm{the} \mathrm{effect} \mathrm{of}$ $M$. arvalis on the production from a mean ha of plantations one should take into consideration these differences in vole density.

Our investigations confirmed a well known thesis that predators are not able to prevent the mass apperance of rodents (E I to n, 1942; Erringt on, 1946, 1963; B a š e $n$ in a, 1962). In the years of low vole density, i.e. 1969/70 predators caused a considerable reduction of $M$. arvalis population (R s zkowski et al., 1971) and despite this a continuous increase in the number of common voles was observed until the outbreak in summer 1971. The increase in the density of rodents was reflected in predators diet, what also was abserved by other investigators (e.g. Pavlov \& Kiris, 1956; Macpherson, 1969; Scott, $1943 ;$ Rusch, Meslow, Doerr \& Keith, 1972; W agner \& S to d d a r t, 1972, and several others).

The functional reaction of predators ( $\mathrm{S}$ ol o mon, 1949) to the mass occurrence of voles, apart from changes in the diet, was manifested by weasels which stored in stacks killed rodents. Out of them only field voles were consumed. As demonstrated by snow-trackings in winter 1971/72 foxes passed by dead rodents without touching them. Also only in the year of mass occurrence dead voles devoid of heads were found below resting places of T. alba. These phenomena could not be quantitatively determined and hence were not taken into account in the estimation of predators pressure on rodents. This may lead to underestimating the pressure of weasels, which are known to be able of killing much more victims than they can consume (H e ptner et al., 1967).

Predators hunt mainly in places of a high rodents density, but in parallel to a general increase of the density the differentiation of hunting areas disappears. This may probably explain a high pressure of predators 
on rodents in the years of low vole numbers. Predators can find groups of vole colonies where their availability may be relatively high despite low total density in the whole area. Cats constitute the exception among predators, since in the years of low vole density they utilize almost exclusively food supplied by man or found in the farm. Pearson (1971) suggested that although the predators do not prevent the mass appearance of rodents their pressure after the peak density was reached affects the amplitude and synchronization of changes in the population numbers. However, P e a r s o n (1971) did not take into consideration the effect of spatial arrangement of the prey on the efficiency of predator action, hence his conclusions should be probably limited to local situations.

2. It was found that in the years of low vole density a higher spatial differentiation in the vole population occurs. Individual colonies are situated in a distance from each other, and in some cultures they are inhabited by few animals. In the plantations of perennial plants, where vole colonies are well developed despite constant hunting of predators, this species occurs always and in the highest density. From this area voles migrate to other habitats. The importance of spatial differentiation in the predator-prey relationship among invertebrates was emphasized by $\mathrm{Huffaker}$ (1957).

As demonstrated by our investigations functional reactions of the studied predators are considerably differentiated (Strix aluco changes the diet to voles most early, while martens shows almost a year delay). The causes of these differences are not known but they indicate a considerable complexity of relationships between common voles and their predators. The mass occurrence of rodents causes a decrease in the pressure of predators on other species of prey. By analysing the bird pellets of five species of predatory birds Korschgen \& Stuart (1972) demonstrated that the rise in the proportion of rodents in the diet is accompanied by reduction of hares share. Our studies demonstrated also that chances of survival of forest rodents increased in effect of change of the predators diet to voles.

In further studies on the trophic relationships of $M$. arvalis more accurate determination of the following parameters is planned:

a) Estimates of variations of the average length of life of rodents in different years and in different habitats. This task is particularly difficult in the case of $M$. arvalis since up to now no criteria are known how to distinguish age classes of individuals in the population.

b) Importance of migrations of rodents between distinguished habitats, e.g. demonstrated in this study mass summer migrations of A. agrarius made impossible accurate estimates of their numbers in the vegetation 
period. This problem is associated with elaboration of correct methods of density estimation among rodents inhabiting balks and meadows.

c) Elaboration of methods of numbers estimation of animals in stacks, e.g. for the lack of such method the data on the number of weasels should be considered as underestimated. This problem is also related to numbers of rodents in general, since in winter a continuous reproduction of rodents in stacks was ascertained.

d) Estimates of selective action of predators. The investigations on the food brought to the nest by buzzards indicate that the assumption used in this study on the lack of selection of weight classes of the prey may be not true. This fact may explain discrepancies between the obtained estimates of predators pressure expressed in the number of consumed individuals $(18 \%)$ and from the calculation of energy values $(30.6 \%)$.

Despite numerous inevitable simplifications it appears that the obtained general picture of ecological meaning of $M$. arvalis population in agrocenoses reflects the real situation. The effect of common voles on vegetation is complicated and cannot be estimated on the basis of censuses, occasionally carried out, e.g. winter damages to corns not always result in a loss of the further crop. Althoug agrocenoses are characterized by simplicity of structure the processes of biocenotic regulation based on the relation predator-prey are very complicated. The common vole affect indirectly the numbers of forest rodents as well as game (hares) through the complex of their predators.

\section{REFERENCES}

1. B a šenina N. V., 1962: Ekologia obyknovennoj polevki i nekotorye čerty ee geografičeskoj izmenčivostii. Izd. Moskov. Univ.: 1-310. Moskva.

2. B obek B., 1969: Survival, turnover and production of small rodents in a beech forest. Acta theriol., 14, 15: 191-210.

3. Chitty D., 1957: Adverse effects of population density upon the viability of later generations. [In: "The numbers of man and animals". Eds. Cragg J. B. \& Pirie N. W.]. Oliver and Boyd: 57-67. London.

4. Czarnecki Z., 1956: Obserwacje nad biologią sowy uszatej, Asio otus (L.). Pr. Kom. biol. Poznań., 18, 4: 1-38.

5. D rożdż A., 1969: Digestibility and utilization of natural food in small rodents. [In: "Energy flow through small mammal populations". Eds. Petrusewicz K. \& R y sz k ow ski L.]. Polish Sci. Publi.: 127-130. Warszawa.

6. E1t on C., 1942: Voles, mice and lemming. Oxford Univ. Press: 1-496. London.

7. Errington P. L., 1946: Predation and vertebrate population. Quart. Rev. Biol., 21: 144-177, 221-245.

8. Frank F., 1957: The causality of microtine cycles in Germany. J. Widl. Mgmt., 21: $113-121$.

9. Golley F. B., 1960: Energy dynamics of a food chain of an old-field community. Ecol. Monogr. 30: 187-206. 
10. Grodziński W., Górecki A., Janas K. \& Migula P., 1966: Effect of rodents on the primary productivity of alpine meadows in Bieszczady Mountains. Acta theriol., 11, 8: 419-431.

11. Grodziński W., Pucek Z. \& Ryszkowski L., 1966: Estimation of rodent numbers by means of prebaiting and intensive removal. Acta theriol., 11, 9: $297-314$.

12. Grodziński W. \& Górecki A., 1967: Daily energy budgets of small rodents. [In: "Seconodary productivity of terrestrial ecosystems«. Eds. Petrus e wi c z K.]. Polish Sci. Publi.: 295-314. Warszawa.

13. Grodziński W., Bobek B., Drożdí A. \& Górecki A., 1969: Energy flow through small rodent populations in a beech forest. [In: $\$$ Energy flow through small mammal populations«. Eds. K. Petrusewicz \& L. R y szk ow ski]. Polish Sci. Publ.: 291-298. Warszawa.

14. Heptner V. G., Naumov N. P., Jurgenson B. P., Sludskij A. A., Cirkova A. F. \& Bannikov A. G., 1967: Mlekopitajuščie Sovetskovo Sojuza. Izd. Vysšaja Škola, 2: 1-1004. Moskva.

15. Holišova V., 1968: Marking small mammals by means of coloured admixtures to bait. Small Mammal Newslet. 2, 3: 36-40.

16. Huffaker C. B., 1957: Fundamentals of biological control of weeds. Hilgardia, 27: 101-167.

17. Korschgen J. L. \& Stuart H. B., 1972: Twenty years of avian predator-small mammal relationships in Missouri. J. Wildl. Mgmt., 36, 2: 269-282.

18. Kratochvíl J., 1959: Hraboš polni Microtus arvalis. Ceskoslovenské Akademie Věd: $1-355$. Praha.

19. Li e th H., 1968: The measurement of caloric values of biological material and the determination of ecological efficiency. [In: "Functioning of terrestrial ecosystems at the primary production level«. Ed. Eckard F. E.]. Unesco.: 233243. Paris.

20. Lockie J. D., 1959: The estimation of the food of foxes. J. Wildl. Mgmt., 23, 2: $224-227$.

21. Macpherson A. W., 1969: The dynamics of Canadian arctic fox populations. Canad. Wildl. Service, 8: 1-52. Ottawa.

22. M a ksimov A. A., 1964: Selskohozjajstvennoe preobrazovanie landsafta i ékologija wrednyh gryzunov. Izd. Nauka: 1-238. Moskva.

23. O dum E. P., 1971: Fundamentals of ecology. Saudner Comp.: 1-574. Philadephia.

24. Pavlov M. P. \& Kiris J. B., 1956: Pitanie lisicy (Vulpes vulpes L.) V prizovskih plavniah Kubanii zasielonnych nutrej (Myocastor coypus M o 1.). Zool. Ž. $35,6: 897-908$.

25. Pears on O. P., 1971: Additional measurement of the impact of carnivores on California voles (Microtus californicus). J. Mammal. 52, 1: 41-49.

26. Petrov O. V., 1963: Pitanie myševidnyh gryzunov lesostepnyh dubrav v laboratornyh uslovijah. Vopr. Ekol. Životn. 8: 119-174.

27. Pucek Z., Ryszkowski L. \& Zejda J., 1969: Estimation of average length of life in bank vole, Clethrionomys glareolus ( $\mathrm{S} \mathrm{ch} \mathrm{rebe} \mathrm{r,} \mathrm{1780).} \mathrm{[In:}$ „Energy flow through small mammal populations". Eds. Petrusewicz K. \& Ryszkow ski L.]. Polish Sci. Publ.: 187-201. Warszawa.

28. Rusch D. H., Meslow C. E., Doerr P. D. \& Keith L. B., 1972: Response of great horned owl populations to changing prey densites. J. Wildl. Mgmt., 36, 2: 282-297. 
29. Ryszkowski L., 1971: Estimation of small rodent density with the aid of coloured bait. Ann. Zool. Fennici., 8: 8-14.

30. Ryszkowski L. \& Petrusewicz K., 1967: Estimation of energy flow through small rodent population. [In: "Secondary productivity of terrestrial ecosystems«. Ed. K. Petrus ewicz]. Polish Sci. Publ.: 1: 125-146. Warszawa-Kraków.

31. Ryszkowski L., Wagner C. K., Goszczyński J. \& Truszkowski J., 1971: Operation of predators in a forest and cultivated fields. Ann. Zool. Fennici. 8: 160-169.

32. S c ott T. G., 1943: Some food coactions of the northern plains red fox. Ecol. Monogr. 13, 4: 427-479.

33. Si iv on en L., 1948: Structure of short-cycle fluctuation in numbers of mammals and birds in the northern parts of the northern hemisphere. Finnish Game Found. Res., Papers Game Res., 1: 1-166.

34. S olom on M. E., 1949: The natural control of animal population. J. Anim. Ecol., 18: $1-35$.

35. Spitz F., 1970: Démographie de Microtus arvalis Pallas dans l'ouest de la France et techniques de surveillance. [In: "Report of the International Conference on Rodents "]. EPPO Publ. Ser. A 58: 61-65.

36. Szuman J., Woliński Z. \& Kulikow ski J., 1955: Zwierzęta Futerkowe. Państ. Wyd. Rol. i Leśn. 1-452. Warszawa.

37. Trojan P., 1969a: An ecological model of the costs of maintenance of Microtus arvalis ( $\mathrm{P}$ a li.). [In: "Energy flow through small mammal populations«. Eds. Petrusewicz K. \& Ryszkowski L.]. Polish Sci. Publ.: 113-122. Warszawa.

38. Trojan P. 1969b: Energy flow through a population of Microtus arvalis ( $\mathrm{P}$ a 11.) in an agrocenosis during a period of mass occurence. [In: "Energy flow through small mammal populations « Eds. Petrusewicz $\mathrm{K}$ \& Ryszkowski L.]. Polish Sci. Publ.: 267-279. Warszawa.

39. W a gner F. H. \& S toddart L. C., 1972: Influence of coyote predation on black-tailed jackrabbit population in Utah. J. Wildl. Mgmt., 36, 2: 329-343.

40. Lockie J. D. \& East K., 1964: Observation on a family of weasels (Mustela nivalis) bred in captivity. Proc. zool. Soc. Lond. 143, 2: 359-363.

Accepted, March 20, 1973.

Polish Academy of Sciences,

Institute of Ecology,

Department of Agroecology,

64-003 Turew, Poland. 


\section{Lech RYSZKOWSKI, Jacek GOSZCZYŃSKI i Janusz TRUSZKOWSKI ZNACZENIE MICROTUS ARVALIS W POWIAZZANIACH TROFICZNYCH AGROCENOZ}

\section{Streszczenie}

Celem pracy było określenie powiązań troficznych $\boldsymbol{M}$. arvalis, czyli wpływu populacji tego gatunku na roslinność terenu oraz presji na badaną populację zespołu drapieżników. Badania prowadzono na obszarze 3100 ha pól i różnego typu zadrzewień w okolicach Turwi, woj. Poznań (Tabela 1). Omawiane w pracy rezultaty badań obejmują okres od $15 \times 1970$ r. do 31 III 1972 r., jednakże prowadzone uprzednio badania (R y szkowski et al., 1971) pozwalają prześledzić niektóre prawidłowości już od lata $1969 \mathrm{r}$.

Zagęszczenie $M$. arvalis na polach oceniano po wypłoszeniu zwierząt wodą na znanym obszarze. W okresie badań prześledzono cykl wahań liczebności populacji od ilości znikomych do załamania się szczytu liczebności (Tabela 2, 3). Z ocen zagęszczeń wykorzystując dane o średniej długości życia nornika oceniono liczbe osobników obecnych na uprawach w okresie badań na $3,4 \mathrm{mln}$ osobników. Stwierdzono, że najwyższe zagęszczenia występują na uprawach wieloletnich. Oddziaływują one zasadniczo na liczebność populacji całego terenu (Tabela 3).

Zagęszczenie gryzoni leśnych (C. glareolus, A. flavicollis, A. agrarius) oceniono przy pomocy zmodyfikowanej metody Standard Minimum. Wyliczono również liczbę osoboników obecnych na terenie badań w wyróżnionych okresach (Tabela 4, 5). Zbadano wielkość strat wywołanych przez nornika na lucernie w roku o jego małej i dużej liczebności (44 os/ha i 774 os/ha). Wzrost zagęszczenia spowodowal wzrost strat z $1,4 \%$ do $21,4 \%$ (Tabela 8) przy wzroście konsumpcji lucerny z $79 \mathrm{~kg} \mathrm{sm} / \mathrm{ha}$ do $1153 \mathrm{~kg} \mathrm{sm} / \mathrm{ha}$ (Tabela 7). Konsumpcja na średni hektor zasiewów i ląk badanego terenu była $w$ roku masowego pojawu około czterokrotnie niższa niż na lucernie $(263 \mathrm{~kg} \mathrm{sm} / \mathrm{ha}$ ). Stwierdzono, że zniszczenia żyta wywołane przez nornika w okresie jesieni i zimy mogą być przez roślinę rekompensowane. Różnica w biomasie części nadziemnych $\mathrm{z}$ miejsc wyżerowanych przez norniki a nieruszonych stopniowo zmniejsza się. W czasie żniw brak już wpływów pogryzów na plon (Tabela 9$)$.

Równolegle $\mathrm{z}$ ocenami liczebności gryzoni prowadzono oceny liczebności szeregu drapieżnych ptaków i ssaków (Tabela 11). Dietę ich badano przeżyciowo poprzez analizę kału, wypluwek, pokarmu piskląt. Jedynie danych do diety Felis catus dostarczały analizy żołądków odstrzelonych osobników. W eksperymentach hodowlanych oszacowano dzienne zapotrzebowanie pokarmowe poszczególnych gatunków drapiéżników (Tabela 12). Znając liczbę obecnych drapieżników, wielkość ich dziennego zapotrzebowania pokarmowego oraz udziału (\% wagowy) norników i myszy w diecie, ich średnie ciężary, wyliczono liczbę zjedzonych drobnych gryzoni (Tabela $13,14)$. Porównano liczbę gryzoni zjadanych przez drapieżniki z ocenami śmiertelności (Tabela 15).

Ze wzrostem zagęszczenia populacji $M$. arvalis udział drapieżników w ogólnej śmiertelności tego gatunku spadł (z $79 \%$ do $10 \%$ ). Presja drapieżników na nornika (rozumiana jako stosunek liczby zjedzonych w danym okresie do liczby dostępnych) także spadła ze wzrostem zagęszczenia ofiary z $49 \%$ na $9 \%$ (Tabela 15). S ol o m on (1949) wyróżnił dwie możliwości reakcji drapieżników na wzrost liczebności populacji swej ofiary: reakcję funkcjonalną i ilościową. W pierwszym wypadku drapieżnik zwiększa udział ofiary w swej diecie, w drugim zwiększa zagęszczenie własnej populacji. 
Obserwowano ostrą reakcję funkcjonalną drapieżników. Zwiększenie się udzialu nornika w diecie osiągnęło około $80 \%$ (Fig. 3) oraz jednocześnie nastąpiło jego wyrównanie w diecie różnych drapieżników. Najszybciej zaszła tu reakcja u puszczyka; kuny reagują dopiero na szczytowe stany liczebności (Fig. 4). Wyraźną reakcję ilościową, przejawiającą się zwiększeniem liczby osobników, obserwowano jedynie u myszołowa i kota (Tabela 11). Obserwacje polujących drapieżników i tropienia zimowe wskazują, że najintensywniej penetrowane są uprawy wieloletnie (lucerny i łąki), na których zagęszczenia nornika są najwyższe (Tabela 17, 18, 19). Przejście większości drapieżników na odżywianie się głównie nornikiem spowodowało spadek redukcji populacji gryzoni leśnych i zwiększyło szanse ich przeżycia (Tabela 15). Obfitość nornika wpłynęła również na wyraźny spadek udziału zajęcy w diecie lisa (Fig. 6). Presja drapieżników M. arvalis jest wyższa przy niskich stanach zagęszczenia jego populacji, spadając w miarę zwiększania zagęszczenia, ponieważ drapieżniki mimo przestawienia diety głównie na norniki oraz u pewnych gatunków zwiększenie liczebności nie są $w$ stanie zahamować eksplozywnego wzrostu populacji ofiary. Praca niniejsza oraz przeprowadzone równocześnie w Zakładzie Agroekologii prace nad bilansem radiacyjnym i produkcją pierwotną umożliwiły zestawienie schematu powiązań troficznych $M$. arvalis w roku o wysokiej jego liczebności (Fig. 7).

Stwierdzono, że z przeciętnego hektara upraw 1,75\% produkcji pierwotnej jest konsumowana przez nornika. Z zasymilowanego pokarmu $2,1 \%$ wykorzystanych jest na produkcję populacji. Globalna konsumpcja biomasy norników przez drapieżniki odpowiada $30,6 \%$. Najintensywniej redukowały populację norników lisy i koty domowe. 